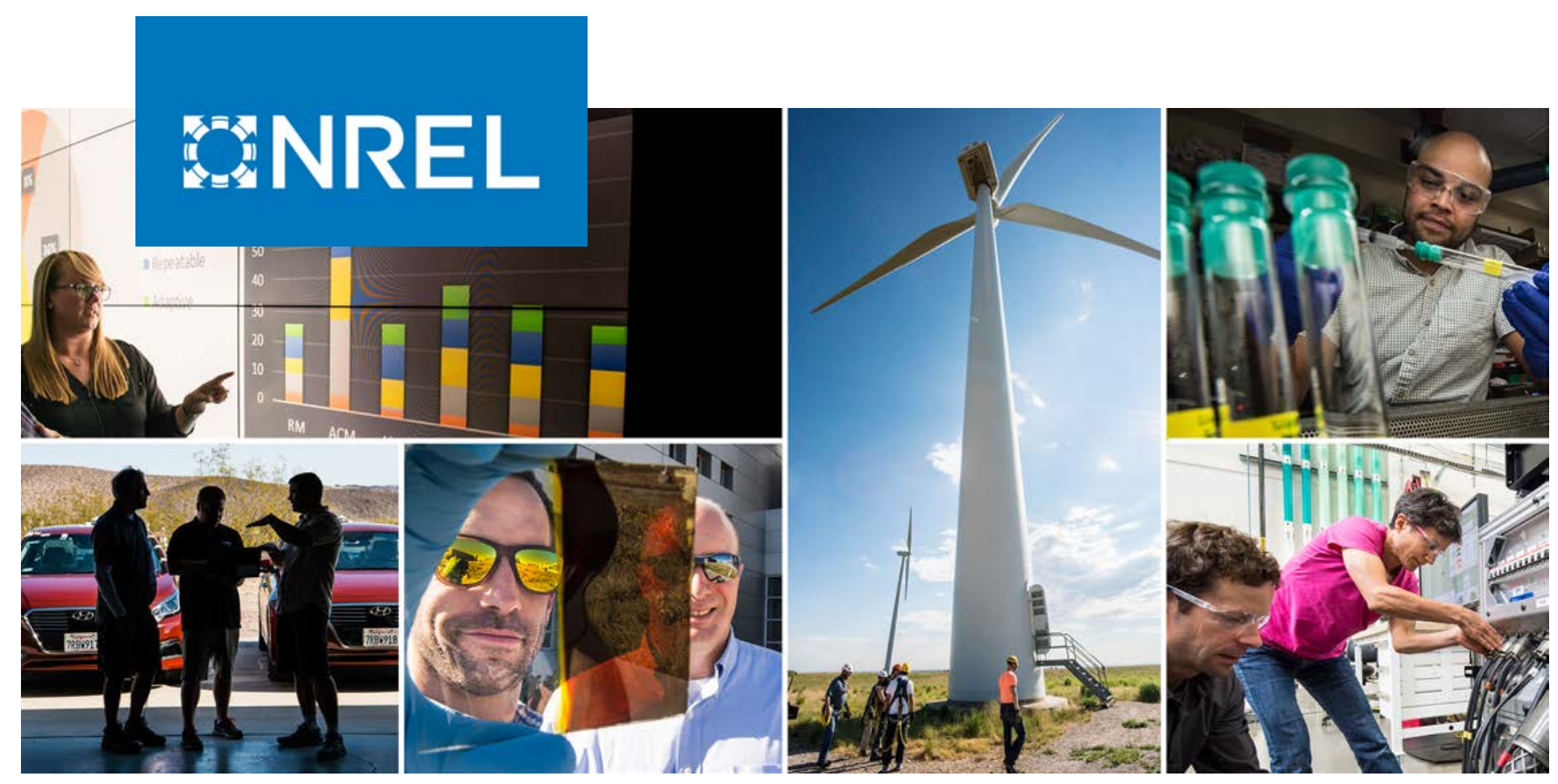

\title{
Up to the Challenge: Communities Deploy Solar in Underserved Markets
}

Jeffrey J. Cook, ${ }^{1}$ Sydney Forrester, ${ }^{1}$ Bryn Grunwald, ${ }^{1}$ Jenny Heeter, ${ }^{1}$ Clark Henry, ${ }^{2}$ and Monisha Shah ${ }^{1}$

1 National Renewable Energy Laboratory

2 International City/County Management Association (ICMA)

NREL is a national laboratory of the U.S. Department of Energy

Office of Energy Efficiency \& Renewable Energy

Operated by the Alliance for Sustainable Energy, LLC

This report is available at no cost from the National Renewable Energy Laboratory (NREL) at www.nrel.gov/publications.

\section{Technical Report}

NREL/TP-6A20-72575

May 2019 


\title{
GNREL
}

\section{Up to the Challenge: Communities Deploy Solar in Underserved Markets}

\author{
Jeffrey J. Cook, ${ }^{1}$ Sydney Forrester, ${ }^{1}$ Bryn Grunwald, ${ }^{1}$ \\ Jenny Heeter, ${ }^{1}$ Clark Henry, ${ }^{2}$ and Monisha Shah ${ }^{1}$ \\ 1 National Renewable Energy Laboratory \\ 2 International City/County Management Association (ICMA)
}

\section{Suggested Citation}

Cook, Jeffrey J., Sydney Forrester, Bryn Grunwald, Jenny Heeter, Clark Henry, and Monisha Shah. 2019. Up to the Challenge: Communities Deploy Solar in Underserved Markets. Golden, CO: National Renewable Energy Laboratory. NREL/TP-6A20-72575. https://www.nrel.gov/docs/fy19osti/72575.pdf.

NREL is a national laboratory of the U.S. Department of Energy Office of Energy Efficiency \& Renewable Energy Operated by the Alliance for Sustainable Energy, LLC

This report is available at no cost from the National Renewable Energy Laboratory (NREL) at www.nrel.gov/publications.

Contract No. DE-AC36-08GO28308
Technical Report NREL/TP-6A20-72575 May 2019

National Renewable Energy Laboratory 15013 Denver West Parkway Golden, CO 80401

303-275-3000 • www.nrel.gov 


\section{NOTICE}

This work was authored in part by the National Renewable Energy Laboratory, operated by Alliance for Sustainable Energy, LLC, for the U.S. Department of Energy (DOE) under Contract No. DE-AC36-08G028308. Funding provided by U.S. Department of Energy Office of Energy Efficiency and Renewable Energy Solar Energy Technologies Office. The views expressed herein do not necessarily represent the views of the DOE or the U.S. Government.

This report is available at no cost from the National Renewable Energy Laboratory (NREL) at www.nrel.gov/publications.

U.S. Department of Energy (DOE) reports produced after 1991 and a growing number of pre-1991 documents are available free via www.OSTI.gov.

Cover Photos by Dennis Schroeder: (clockwise, left to right) NREL 51934, NREL 45897, NREL 42160, NREL 45891, NREL 48097, NREL 46526.

NREL prints on paper that contains recycled content. 


\section{Acknowledgements}

This work was funded by the Solar Energy Technologies Office. The authors would like to thank all the interviewees for contributing their expertise to this study. We would also like to thank the following individuals for their review of this work: Ganesan Visvabharathy (Affordable Solar King), Ben Underwood (Boston Solar Access), Jill Cliburn (Cliburn and Associates LLC), Vicki O’Day (Community Solar for Community Action), Kedin Kilgore (FAC Solar-Gowanus Grid \& Electric), Shubha Jaishankar (Department of Energy), Matt Doyle (Duluth Community Solar Coalition), Ramsey Cripe (Kerrville Area Solar Partners), Bennie Hayden (Marketing for Green LLC), Alison Holm, Travis Lowder, and Jaquelin Cochran (National Renewable Energy Laboratory), Bentham Paulos (Paulos Analysis), Emily Schapira (Philadelphia Energy Authority), Anthony Rose (Power52 Foundation), Mary Rottman (Rottman-Associates), Sarah Conley-Ballew (Solar Access UpGrade Ohio), Dan Conant (Solar Holler), Jim Moran (Solar Synthesizers), David Beavers (Sunvesty), David Hill (Sun Shares [VEIC]), and Mike Myers (Team Wasaya). Finally, we would like to thank Mary Lukkonen, Stacy Buchanan, and Sam Koebrich (National Renewable Energy Laboratory) for their editing and graphics support. 


\section{Executive Summary}

The U.S. Department of Energy (DOE) launched the Solar in Your Community Prize Challenge (SIYC Prize Challenge) in 2016 to identify innovative approaches to support solar deployment among underserved markets, including low- and moderate-income (LMI) populations, nonprofit organizations, and other community-serving entities, such as municipal governments. These sectors face unique barriers relating to financing, ownership structure, and upfront costs. DOE designed the SIYC Prize Challenge to help local teams develop novel approaches to resolve them. This report describes the SIYC Prize Challenge structure, participating teams, their top technical challenges, and profiles 10 innovative teams and related business models. It concludes with some key takeaways that others might consider when developing projects and programs tailored to these market segments. ${ }^{1}$

DOE accepted 178 teams in the SIYC Prize Challenge spanning 40 states, the District of Columbia, Guam, and Puerto Rico. If all the teams successfully execute their business plans, the SIYC Prize Challenge is expected to generate 1,600 MW of solar by 2020 , serving as many as 900 nonprofits and 48,000 LMI households. During the 18-month challenge (May 2017 October 2018), DOE provided teams with technical and financial resources to help them implement their projects. All teams received at least some technical assistance in the form of trainings, workshops, and direct coaching. Also, 121 teams received technical assistance vouchers to pursue additional support from third-party consultants. A smaller set of 34 teams received direct financial resources in the form of seed funds. In 2019, DOE will award five teams final prizes totaling \$1 million.

Teams adopted a range of business models and innovations to better address the unique barriers faced by underrepresented markets. The leading types of innovations were related to financing and opening new markets. Technology innovations, such as pairing solar with other energy technologies or new software, along with novel partnership structures, were also common approaches taken by teams.

The profiled teams are implementing a wide variety of approaches to serve the LMI, nonprofit, and municipal market segments (see Table ES-1). Three of the ten teams are focused specifically on LMI households, while four teams focus on LMI households and nonprofits. Finally, three teams focus on nonprofits, municipal governments, or a combination of the two.

\footnotetext{
${ }^{1}$ This study relied upon archival research and interviews with over 40 subject-matter experts, including DOE personnel, program consultants, coaches, and team members. The interviews revealed innovative approaches and lessons learned based on the experience of all participating teams. Select interviewees also provided perspectives on the 10 profiled teams.
} 
Table ES-1. Comparison of Profiled Teams by Target Market and Business Model/Approach

\begin{tabular}{|c|c|c|c|c|c|c|c|c|c|c|}
\hline \multirow[b]{2}{*}{$\begin{array}{l}\text { Profiled } \\
\text { Team }\end{array}$} & \multirow[b]{2}{*}{$\begin{array}{c}\text { Target } \\
\text { Market(s) }\end{array}$} & \multirow[b]{2}{*}{$\begin{array}{c}\text { Business } \\
\text { Model/Approach }\end{array}$} & \multicolumn{8}{|c|}{ Financing Approach } \\
\hline & & & 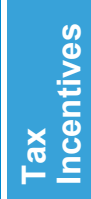 & $\frac{\pi}{\alpha}$ & 孚 & 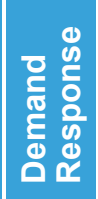 & 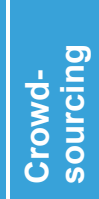 & $\begin{array}{l}0 \\
\& \\
\Phi \\
\mathbb{o}\end{array}$ & 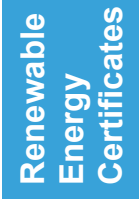 & $\frac{2}{\Phi}$ \\
\hline $\begin{array}{l}\text { Boston Solar } \\
\text { Access }\end{array}$ & $\begin{array}{l}\text { LMI households } \\
\text { and nonprofits }\end{array}$ & $\begin{array}{l}\text { Community solar } \\
\text { hosting }\end{array}$ & $\bullet$ & $\bullet$ & & & & & & \\
\hline $\begin{array}{l}\text { Duluth } \\
\text { Community } \\
\text { Solar Coalition }\end{array}$ & $\begin{array}{l}\text { Nonprofits and } \\
\text { municipal } \\
\text { governments }\end{array}$ & $\begin{array}{l}\text { Crowdsource social } \\
\text { impact investing }\end{array}$ & & & & & $\bullet^{a}$ & & & \\
\hline $\begin{array}{l}\text { FAC Solar- } \\
\text { Gowanus Grid } \\
\text { \& Electric }\end{array}$ & $\begin{array}{l}\text { LMI households } \\
\text { and nonprofits }\end{array}$ & $\begin{array}{l}\text { Solar financing for } \\
\text { nonprofit multi-family } \\
\text { housing }\end{array}$ & $\bullet$ & $\bullet$ & & & & & & $\bullet^{b}$ \\
\hline $\begin{array}{l}\text { Kerrville Area } \\
\text { Solar Partners }\end{array}$ & $\begin{array}{l}\text { LMI households } \\
\text { and nonprofits }\end{array}$ & $\begin{array}{l}\text { LMI community solar } \\
\text { rate design }\end{array}$ & $\bullet$ & $\bullet$ & & $\bullet^{c}$ & & & & \\
\hline $\begin{array}{l}\text { Power52 } \\
\text { Foundation }\end{array}$ & LMI households & $\begin{array}{l}\text { Anchor-supported } \\
\text { LMI community solar }\end{array}$ & $\bullet$ & $\bullet$ & & & & & & \\
\hline $\begin{array}{l}\text { Solar Access } \\
\text { UpGrade Ohio }\end{array}$ & $\begin{array}{l}\text { Municipal } \\
\text { governments }\end{array}$ & $\begin{array}{l}\text { Community-choice- } \\
\text { aggregation-supported } \\
\text { solar deployment }\end{array}$ & & & & & & $\bullet d$ & & \\
\hline Solar Holler & Nonprofits & $\begin{array}{l}\text { Workforce training } \\
\text { and place-based } \\
\text { solar deployment }\end{array}$ & & & $\bullet$ & $\bullet$ & $\bullet$ & & $\bullet$ & \\
\hline $\begin{array}{l}\text { Solar } \\
\text { Synthesizers } \\
\text { Meriden }\end{array}$ & $\begin{array}{l}\text { LMI } \\
\text { households, } \\
\text { nonprofits, and } \\
\text { public housing }\end{array}$ & $\begin{array}{l}\text { Low-income-housing- } \\
\text { tax-credit-supported } \\
\text { solar financing }\end{array}$ & $\bullet$ & $\bullet$ & & & & & $\bullet$ & $\bullet$ \\
\hline Solarize Philly & LMI households & $\begin{array}{l}\text { Solarize program } \\
\text { fees to support } \\
\text { LMI solar leases }\end{array}$ & $\bullet$ & & & & & $\bullet$ & & $\bullet f$ \\
\hline $\begin{array}{l}\text { Sun Shares } \\
\text { (VEIC) }\end{array}$ & LMI households & $\begin{array}{l}\text { Employer-offered } \\
\text { solar program }\end{array}$ & $\bullet$ & & $\bullet$ & & & & & $\bullet$ \\
\hline
\end{tabular}

${ }^{a}$ The Duluth Community Solar Coalition team has not developed a project. When they do complete a project, it is possible they will leverage other financing approaches beyond crowdsource donations or investments.

${ }^{\mathrm{b}}$ The FAC Solar - Gowanus Grid \& Electric team also leveraged a state grant.

${ }^{\mathrm{C}}$ The Kerrville Area Solar Partners team is recovering costs for the PPA through customer participation in a unique community solar rate.

${ }^{d}$ The Solar Access UpGrade Ohio team has not developed a project. When they do complete a project, it is possible they will leverage other financing options beyond collected fees such as a PPA.

e The Solar Synthesizers Meriden team also leveraged energy savings performance contracting, property assessed clean energy, and community reinvestment act financing for some of its projects.

${ }^{\mathrm{f}}$ The Solarize Philly team uses solarize fees to support leases to LMI participants.

$g$ Only a portion of Sun Shares (VEIC) project was funded by a loan, the remaining financing is unknown though it is expected that available tax incentives were monetized. 
Though each of the profiled teams generated unique insights specific to its business model or approach, we conclude with three key takeaways. Communities interested in replicating these approaches in their jurisdictions might consider the following:

- Develop a clear understanding of how federal, state, and local policy enable local solar projects. These policies can influence the team's target audience, project selection, and financing approaches.

- Build durable and long-term partnerships with community members and solar stakeholders. These partnerships can ensure that pilot projects are implemented and followed by second-generation projects for more widespread deployment.

- Develop a creative portfolio of financing solutions for small and medium sized solar projects. Some innovative financing options or approaches may include securing a creditworthy anchor tenant, using crowdsourced funding, compensation from virtual or net metering, or compensation for other grid services.

Overall, this report provides key insights from a subset of innovative projects that demonstrate that expanding solar access to underrepresented markets is economically feasible in a variety of markets. Interested communities may wish to use this report as a resource when considering projects and programs to achieve their own energy-related objectives. 


\section{Table of Contents}

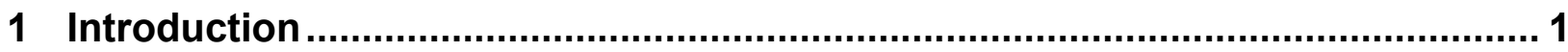

2 SIYC Prize Challenge Program Background ….................................................. 3

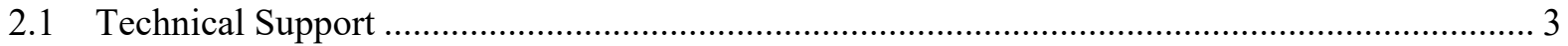

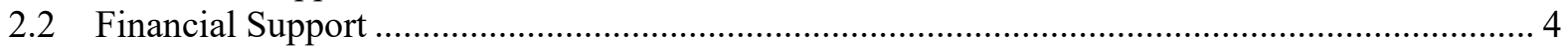

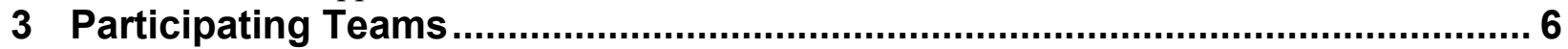

3.1 Lead Project or Program Organizations …………………..................................................

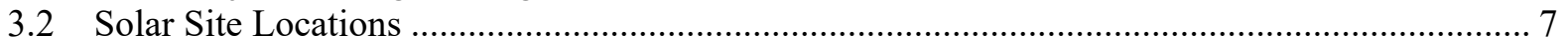

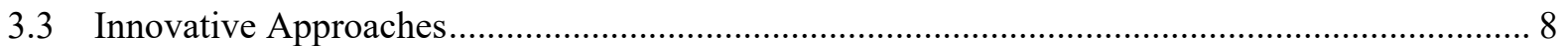

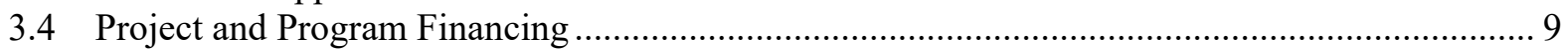

4 Key Challenges and Considerations for PV Project Deployment from the SIYC

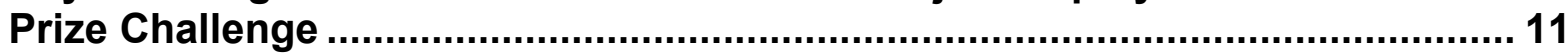

4.1 Financing Barriers and Considerations ……………………………………………….... 13

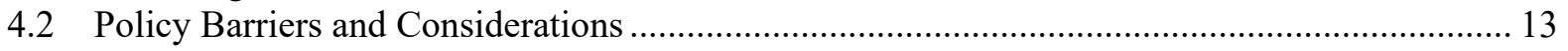

4.3 Legal/Business Structure Barriers and Considerations …………………………………....... 13

5 Profiles of Innovative Teams and Related Market Strategies ......................... 15

5.1 Boston Solar Access: Maximizing LMI Benefits in Solar Hosting Programs ............................. 18

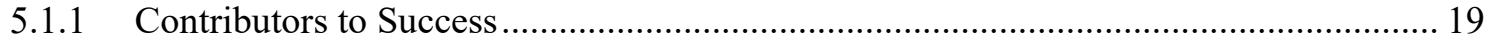

5.1.2 Considerations for Replication............................................................................... 20

5.2 Duluth Community Solar Coalition: Crowdsource Social Impact Investing ……………….....2.21

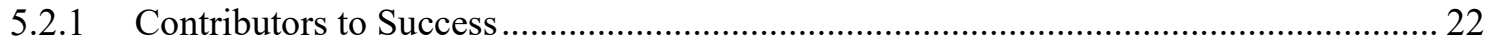

5.2.2 Considerations for Replication.............................................................................. 22

5.3 FAC Solar - Gowanus Grid \& Electric: Unlocking Nonprofit-Owned Multi-Family Housing for

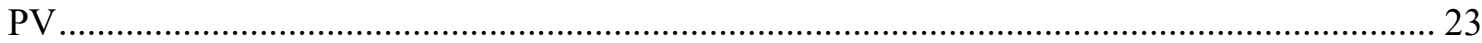

5.3.1 Contributors to Success................................................................................... 24

5.3.2 Considerations for Replication.............................................................................25

5.4 Kerrville Area Solar Partners: Leveraging Municipal Utility Rate Design to Support LMI Solar

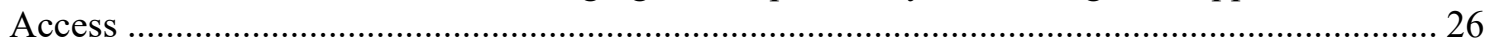

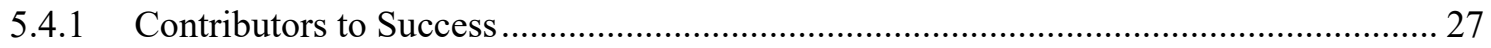

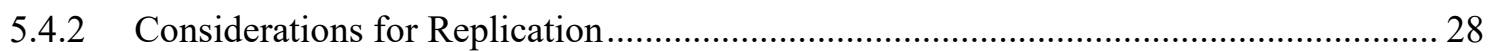

5.5 Power52 Foundation: Leveraging a Corporate Partnership to Support LMI Community Solar in

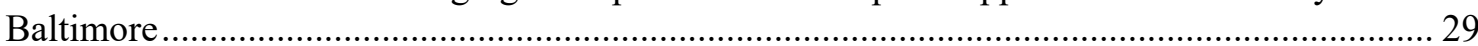

5.5.1 Contributors to Success .................................................................................. 30

5.5.2 Considerations for Replication................................................................................ 30

5.6 Solar ACCESS UpGrade Ohio: Deploying Community Solar Through CCAs ............................ 31

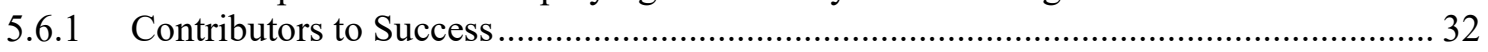

5.6.2 Considerations for Replication ............................................................................ 32

5.7 Solar Holler: Workforce Training and Place-Based Solar Deployment....................................... 33

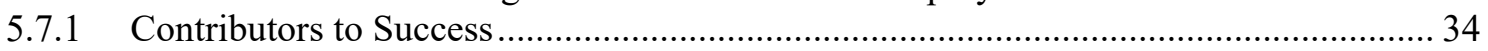

5.7.2 Considerations for Replication.................................................................................. 35

5.8 Solar Synthesizers Meriden: Leveraging Low-Income Housing Tax Credits to Support PV

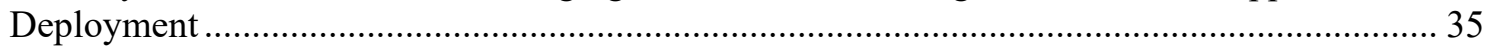

5.8.1 Contributors to Success....................................................................................... 37

5.8.2 Considerations for Replication.................................................................................. 37

5.9 Solarize Philly: Using Solarize Program Fees to Guarantee LMI Solar Leases ……………....... 38

5.9.1 Contributors to Success .................................................................................... 39

5.9.2 Considerations for Replication.............................................................................. 40

5.10 Sun Shares (VEIC): Solar as an Employer-Offered Program ………………………….......... 40

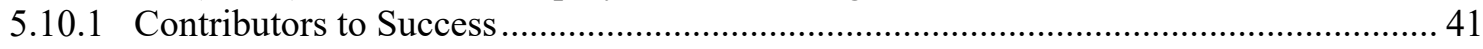




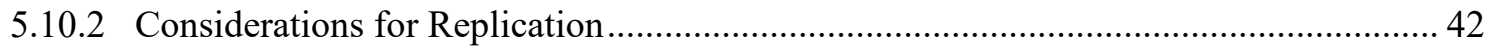

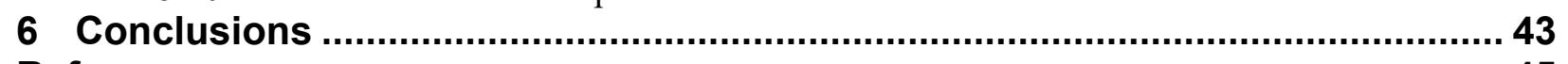

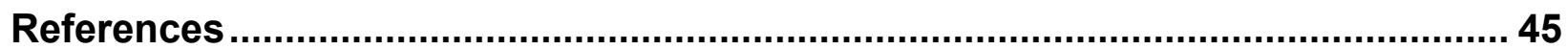




\section{List of Figures}

Figure 1. Geographic distribution of participating teams in the SIYC Prize Challenge ............................ 6

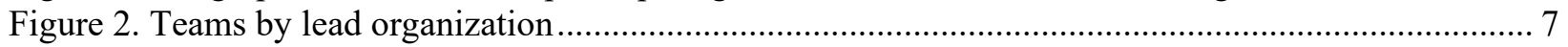

Figure 3. Expected SIYC Prize Challenge solar site locations .................................................... 8

Figure 4. Types of innovative approaches taken by SIYC Prize Challenge teams .................................. 9

Figure 5. Financing mechanisms used in SIYC Prize Challenge projects ........................................... 10

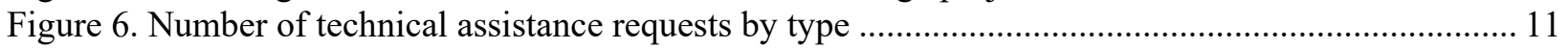

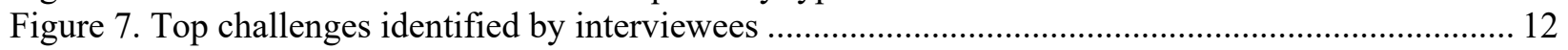

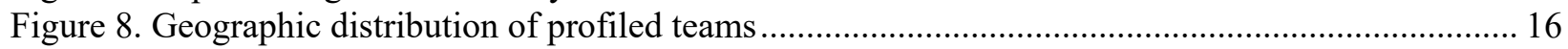

Figure 9. One example of Boston Solar Access program structure …................................................. 19

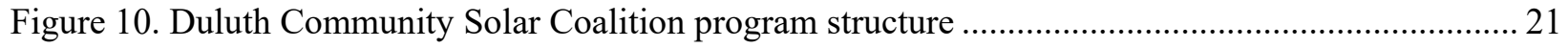

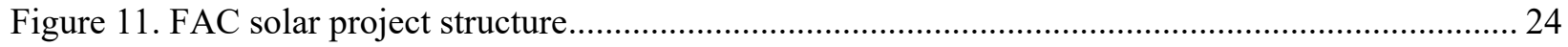

Figure 12. Kerrville Area Solar Partners program structure ............................................................... 27

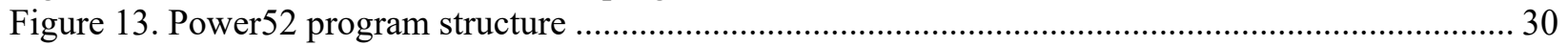

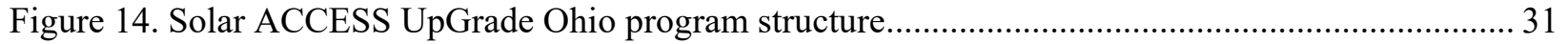

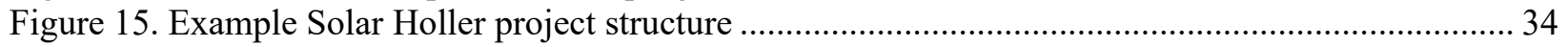

Figure 16. Select Solar Synthesizers LIHTC-supported solar project model ......................................... 36

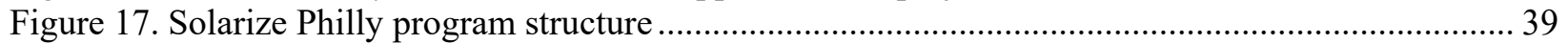

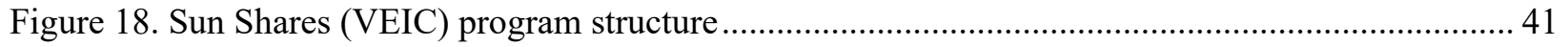

\section{List of Tables}

Table ES-1. Comparison of Profiled Teams by Target Market and Business Model/Approach .................. v

Table 1. Seed Fund Distribution, Allocation, and Milestone Requirements by Team Type ....................... 4

Table 2. Comparison of Profiled Teams by Target Market and Business Model ..................................... 17 


\section{Introduction}

Low- and moderate-income (LMI) residents, nonprofits, and other community-serving entities have been underrepresented in the growing residential solar photovoltaics (PV) market (Barbose et al. 2018). Despite significant rooftop PV potential at LMI homes nationwide (Sigrin and Mooney 2018), existing PV adopter incomes average \$13,000-\$32,000 higher than median income (Barbose et al. 2018). This discrepancy is driven in part by the challenges that LMI residents face when pursuing solar, including home ownership status, roof suitability, upfront solar investment costs, and relatively few financing options tailored to this market segment (Cook and Bird 2018).

These challenges, especially those related to financing, serve as barriers to nonprofits and other community-serving entities. In particular, these market segments often cannot monetize available tax incentives that have helped support PV adoption. These barriers are not unique to rooftop solar and may affect households, nonprofits, and other entities' access to community solar programs.

Innovative approaches to support PV deployment by LMI residents, nonprofits, and other community-serving entities have begun to emerge (Cook and Bird 2018). To accelerate this trend, the U.S. Department of Energy (DOE) launched the Solar in Your Community Prize Challenge (SIYC Prize Challenge) in 2016. In total, DOE selected 178 teams to participate and find innovative pathways to support PV adoption in underserved markets. Teams were composed of a group of local stakeholders such as municipal governments, solar developers, nonprofits, and housing agencies that came together to support the design and installation of a communityoriented solar project or program. If all the teams successfully execute their business plans, the SIYC Prize Challenge could result in 1,600 megawatts (MW) of solar by 2020, serving as many as 900 nonprofits and 48,000 LMI households. ${ }^{2}$

This report provides a summary of the SIYC Prize Challenge design, participating teams, key lessons learned, and profiles 10 teams that have developed especially innovative approaches to serve these markets. These profiles describe the model each community has developed to enable solar deployment, along with the factors that have made it successful and considerations for replication in other markets.

This study relied upon archival research and interviews with over 40 subject-matter experts, including DOE personnel, program consultants, coaches, and team members. The interviews were used to identify innovative approaches and key lessons learned across the experiences of all 178 participating teams. Select interviewees also provided specific insights for the 10 profiled teams.

The remainder of this report is structured as follows. Section 2 describes the design of the SIYC Prize Challenge. Section 3 provides a broad overview of the participating teams and their attributes. Section 4 summarizes some of the key challenges faced by teams along with some considerations for next-generation programs and initiatives targeting these markets. Section 5

\footnotetext{
${ }^{2}$ These estimates are based on an assessment of each team's initial application to the SIYC Prize Challenge.
} 
includes the profiles of 10 teams and provides perspectives on how to deploy these approaches nationwide. Section 6 concludes with key takeaways from the SIYC Prize Challenge and profiled teams for future project or program design. 


\section{SIYC Prize Challenge Program Background}

On November 21, 2016, DOE launched the SIYC Prize Challenge to facilitate replicable business models that bring solar to LMI, nonprofit, state, local, tribal, and other communityserving entities that face financing, regulatory, and technological barriers. To meet this challenge, DOE offered $\$ 4$ million in technical and financial resources to grassroots teams. The challenge will conclude in 2019 when DOE will announce \$1 million in final prizes distributed across the five most innovative teams.

DOE selected teams through a competitive application process. ${ }^{3}$ In total, over 200 teams applied to participate in the challenge and 178 were accepted in two tracks: project or program. Teams that self-selected the project track were intent on developing a specific PV project(s), while those that selected the program track were focused on creating a new approach or model to support solar deployment within the LMI, nonprofit, and/or other community-serving markets.

Over the 18-month performance period (May 2017-October 2018), participating teams were "challenged" to develop innovative, replicable, and scalable models for solar energy deployment that directly benefit LMI communities, nonprofit organizations, and other entities. Projects and programs targeted at LMI populations were expected to direct at least $20 \%$ of the electricity generated from solar installations to LMI households. For projects at nonprofit or other community-serving entities, the target was $60 \%$ of electricity generation benefiting the relevant market segment. ${ }^{4}$

Those teams that were accepted in the program had the opportunity to receive technical and/or financial support to help meet the goals of the challenge. All teams were provided some technical support, with many teams also receiving at least some financial support. The description and allocation of this support is summarized in the sections that follow.

\subsection{Technical Support}

DOE offered technical support for accepted teams, including an assigned coach and access to a variety of training materials, events, and workshops. Through a competitive application process, 24 coaches were selected, with each coach to help 5-10 teams implement their projects or programs. In this capacity, coaches served as sources of information and could help teams identify technical assistance (TA) resources to carry out their projects. They also helped ensure compliance with the rules of the challenge and were required to communicate team progress to DOE and the SIYC Prize Challenge administrator. ${ }^{5}$

In addition to being assigned a coach, all teams had access to educational resources on the SIYC Prize Challenge's website. ${ }^{6}$ Teams could participate in the online solar curriculum that provided trainings on policy, project design, customer acquisition, and financing (Solar in Your

\footnotetext{
${ }^{3}$ https://www.energy.gov/eere/solar/sunshot-prize-solar-your-community-challenge

${ }^{4}$ https://www.solarinyourcommunity.org/rules.html

5 The SIYC Prize Challenge administrator for the first half of the SIYC Price Challenge was the State University of New York system, while the International City/County Management Association (ICMA) was selected as the administrator for the last half of the challenge.

${ }^{6}$ The website can be accessed at https://www.solarinyourcommunity.org/.
} 
Community 2018). The website also included links to reports, case studies, best practices, videos, project questionnaires, and template financial models.

Throughout the course of the program, DOE sponsored events, conferences, and workshops where teams could troubleshoot their projects with their peers, identify key lessons learned, and discuss best practices across teams for addressing certain challenges. For example, DOE and Cadmus, a consulting firm, hosted a 2-day workshop on March 13-14, 2018, with sessions to help teams address financing, regulatory, and other technical challenges associated with their projects or approaches. Teams were also offered free access to one-on-one sessions with proven experts in the regulatory, technology, and financial sectors of the solar industry.

\subsection{Financial Support}

In addition to the technical resources offered to all teams, some received financial resources. DOE provided two types of financial assistance: seed funds and TA vouchers.

A limited amount of seed funds were distributed to 34 teams in Round 1. If a team successfully met all their milestones (e.g. project approvals, financing, and underserved market participation), it could receive up to $\$ 60,000$ in direct financial assistance. Seed funding allocations varied by round and project size (small projects: $<100$ kilowatts $[\mathrm{kW}]$; large projects: $\geq 100 \mathrm{~kW}$ ) (see Table 1). Over the course of the program, nine teams successfully achieved all four milestones and received their full allotment of seed funds. ${ }^{7}$

Table 1. Seed Fund Distribution, Allocation, and Milestone Requirements by Team Type

\begin{tabular}{lll}
\hline \multicolumn{1}{c}{ Distribution } & $\begin{array}{c}\text { Small Project/Large } \\
\text { Project }\end{array}$ & \multicolumn{1}{c}{ Milestone } \\
\hline Round 1: Selection & $\$ 6,000 / \$ 15,000$ & $\begin{array}{l}\text { Active participant and selected by DOE to receive } \\
\text { seed funding }\end{array}$ \\
\hline Round 2: Permission & $\$ 6,000 / \$ 15,000$ & $\begin{array}{l}\text { Program teams: Approval of program design from } \\
\text { governing board or authority } \\
\text { Project teams: Obtained permits }\end{array}$ \\
\hline Round 3: Financing & $\$ 8,000 / \$ 20,000$ & $\begin{array}{l}\text { Program teams: Evidence of approved } \\
\text { appropriations or other agreements } \\
\text { Project teams: Loans, cash on hand, crowdfunding } \\
\text { awards, or anything proving they have secured } \\
\text { financing }\end{array}$ \\
\hline Round 4: LMI Bonus & $\$ 4,000 / \$ 10,000$ & $\begin{array}{l}\text { Program team: Program has launched and at least } \\
50 \% \text { energy forecast to serve LMI households } \\
\text { directly } \\
\text { Project teams: Customer acquisition complete and } \\
\text { at least } 50 \% \text { energy delivered to LMI households }\end{array}$ \\
\hline
\end{tabular}

\footnotetext{
${ }^{7}$ The nine teams include Clean Affordable Solar for All, Community Solar for Community Action, Just Community Solar, Kerrville Area Solar Partners, RE-volv, Solar Pioneers, Solar Synthesizers Meriden, Team Wasaya, and Baltimore Shines. For more information on these teams see: https://www.solarinyourcommunity.org/teams.html.
} 
In addition to seed funding for certain project teams, teams were eligible to receive free assistance from a consultant via a technical assistance voucher program. DOE selected 121 teams to receive free assistance and selected 126 consultants ("TA providers") via a separate competitive selection process to provide assistance. ${ }^{8}$ Teams that were awarded free assistance (up to $\$ 10,000$ per voucher) could spend their allocation of funds via an online marketplace ("TA marketplace"). ${ }^{9}$ All transactions were facilitated through the online platform and managed by the SIYC Prize Challenge administrator. This allowed teams to avoid entering into contractual arrangements directly with consultants. Over the performance period, about $\$ 2$ million in vouchers was allocated to teams of which $\$ 1.5$ million was spent in the marketplace.

\footnotetext{
${ }^{8}$ These consultants were selected from a pool of 314 consultants who began the application process. Many of these applicants did not complete the process, so their applications were not considered in the selection process.

${ }^{9}$ Each voucher was worth $\$ 10,000$ of services in the TA marketplace, and teams could receive more than one voucher.
} 


\section{Participating Teams}

One of the primary objectives of the program was to incubate innovative rooftop and community solar projects with a wide variety of organizations nationwide. In total, 178 teams were accepted into the SIYC Prize Challenge, and no two are exactly alike. ${ }^{10}$ Their profiles showcase a diversity in partnership and collaboration among businesses, nonprofit organizations, local governments, and individuals. From Maine to Alaska, teams created new models for bringing solar energy to LMI households, nonprofits, and other community-serving entities (see Figure 1).

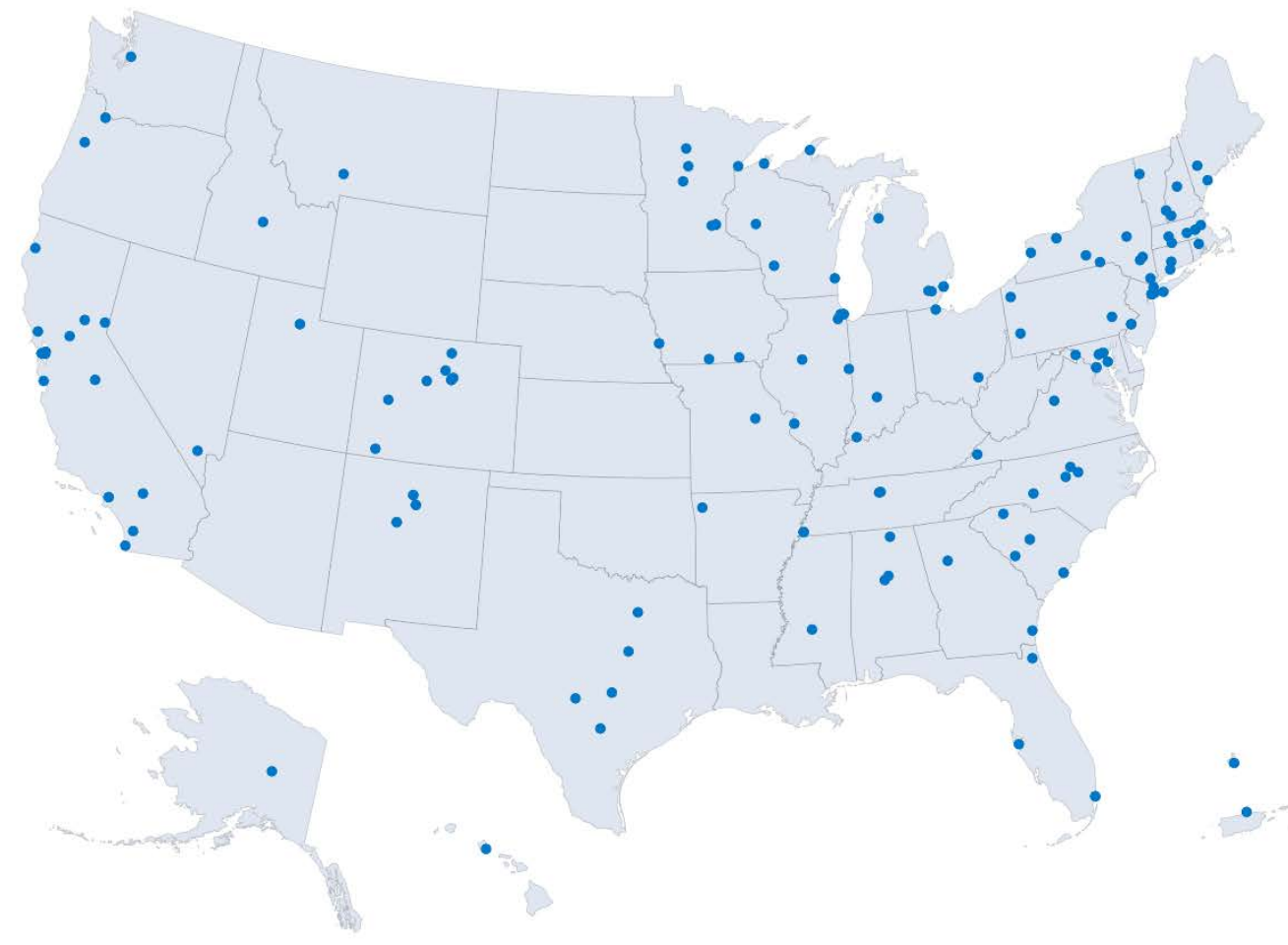

Figure 1. Geographic distribution of participating teams in the SIYC Prize Challenge

Teams represented over 40 states, districts, and territories across the United States. While states with robust solar or community solar markets, such as California, New York, Illinois, and Minnesota, had over 10 teams, several other states with more emerging markets such as Michigan, Pennsylvania, South Carolina, and Texas had five or more. The remainder of this section compares participating teams by lead organization, project location, financing, and innovation.

\footnotetext{
${ }^{10}$ Additional information on all the teams can be accessed at https://www.solarinyourcommunity.org/teams.html.
} 


\subsection{Lead Project or Program Organizations}

A wide variety of organizations led SIYC Prize Challenge teams. Most teams were led by forprofit organizations, typically local solar or renewable energy companies. In some cases, these for-profit organizations were new market entrants, such as the HBCU Coalition, a minorityserving institution leading the HBCU Clean Energy Consortium in Florida. Community-based nonprofits were the second-most common organization to lead teams, followed by local governments, community groups, and utilities (Figure 2).

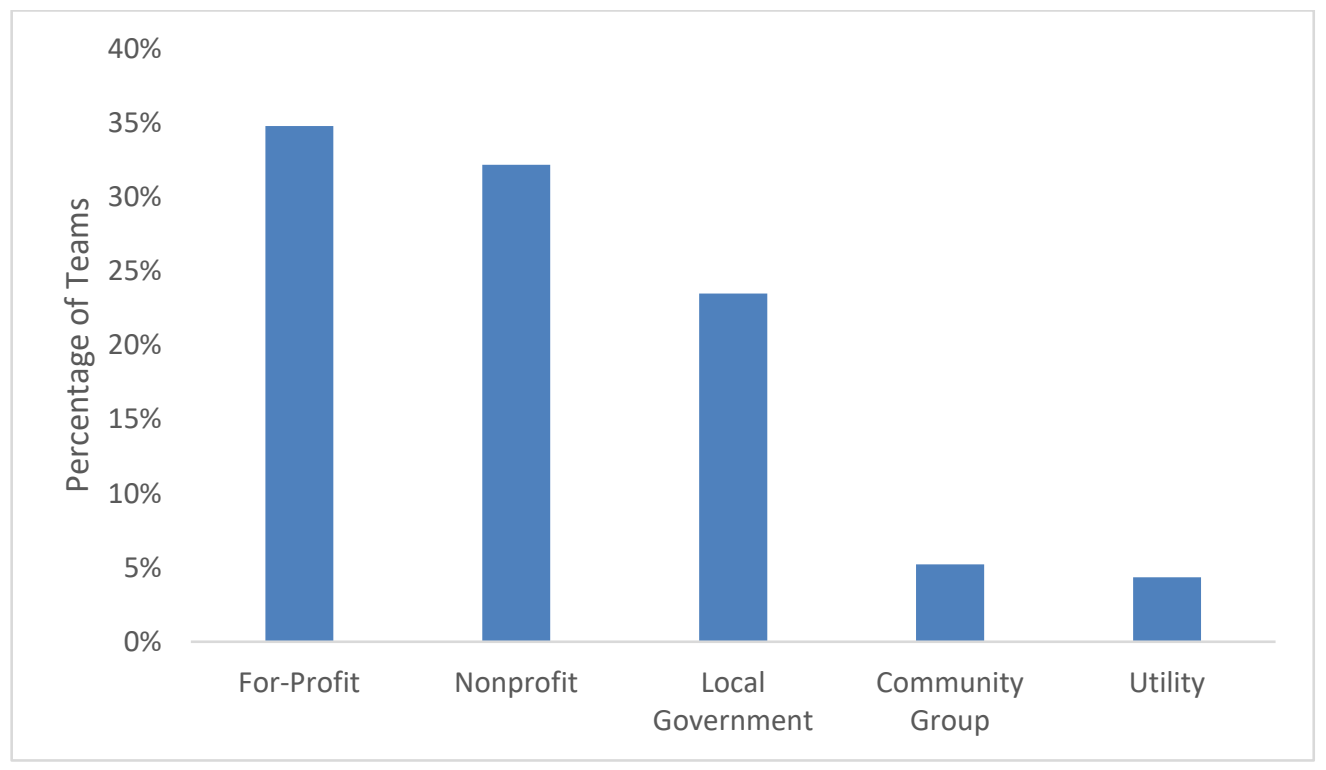

Figure 2. Teams by lead organization

This figure is based on the 115 teams where a lead organization was identified based on the team's initial application.

\subsection{Solar Site Locations}

Teams pursued a range of locations for their rooftop and community solar projects from municipal buildings to brownfields (see Figure 3). Most teams planned to locate solar projects on at least some municipal buildings, reflecting local government involvement in teams. Singlefamily homes and multi-family buildings were two of the more common locations to deploy solar that benefitted low-income households. Local nonprofits and schools also served as sites for systems, including three Texas nonprofits associated with the Kerrville Area Solar Partners team (profiled in Section 5). Religious institutions, tribal lands, and brownfields were also selected for solar projects, such as the St. Stephen's Episcopal Church in Virginia, the Blue Lake Rancheria Reservation in California, and the Ecogy Solar for Affordable Housing brownfield project in Delaware. 


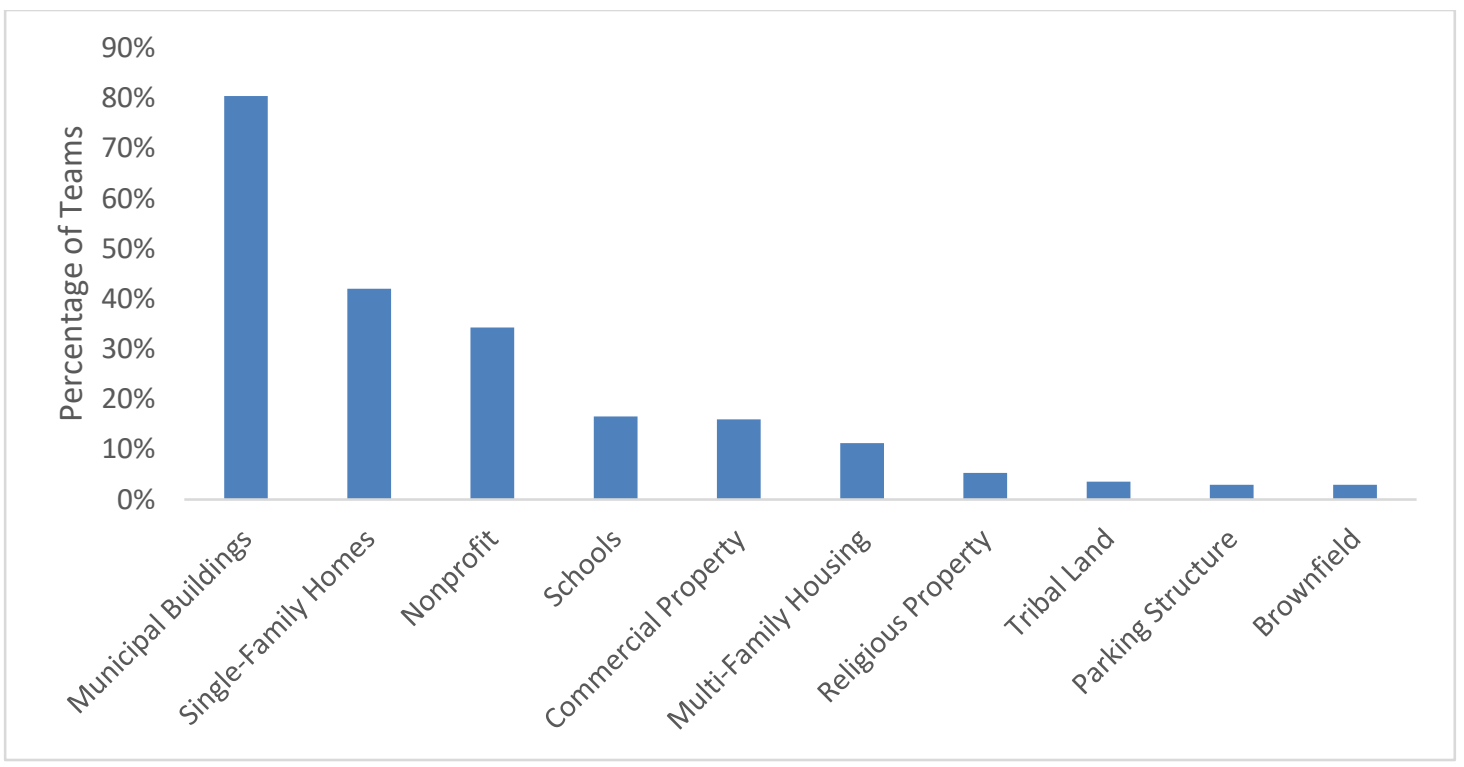

Figure 3. Expected SIYC Prize Challenge solar site locations

This figure is based on the 161 teams where a project location(s) was identified based on the team's initial application.

\subsection{Innovative Approaches}

Collectively, teams developed innovative approaches through a combination of new financing models, markets, technologies, and partnerships to achieve their objectives (see Figure 4). Innovations around financing projects were most common across teams, and these pathways are discussed in detail in Section 3.4. Many teams were focused on deploying solar in a new market, such as rural and tribal communities, and more challenging market segments, such as multifamily housing and mobile home communities. In addition, some teams incorporated new technologies or partnerships into their projects. In terms of technology, some teams were focused on pairing solar with other technological advances such as energy efficiency measures, electric vehicles, and microgrid controls. For example, the Community Clean Energy Project in Massachusetts incorporated energy efficiency, demand response, and PV to right-size PV systems and maximize savings for LMI households in their project. Teams pursued a variety of innovative partnerships that included affordable housing providers, community organizations, commercial partners, and households. Lastly, some teams incorporated policy and workforce training opportunities, including training former coal miners as done by the Solar Holler team in West Virginia (profiled in Section 5). 


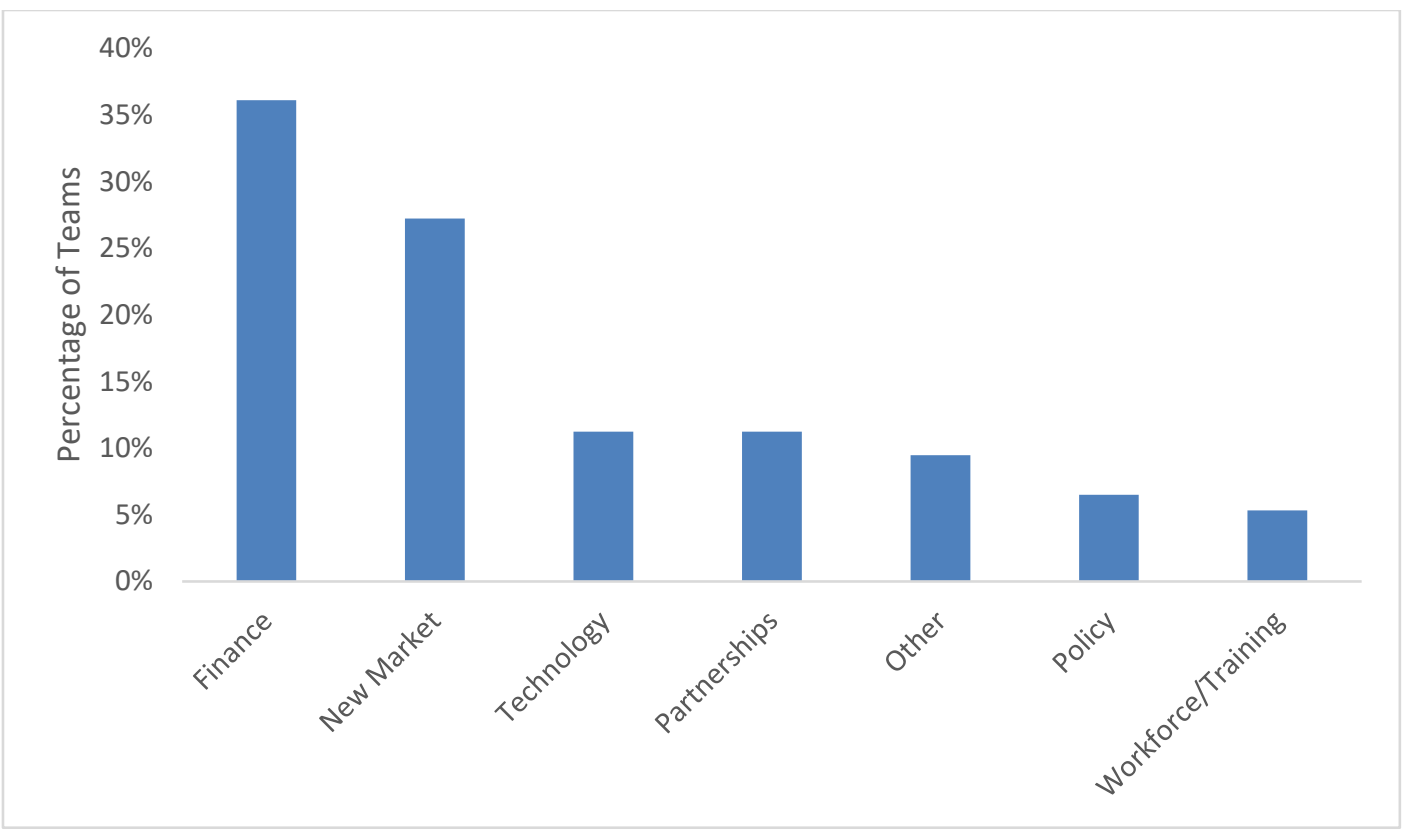

Figure 4. Types of innovative approaches taken by SIYC Prize Challenge teams

This figure is based on the 155 teams where an innovative approach was identified based on the team's initial application.

\subsection{Project and Program Financing}

Financing is one of the key deployment barriers in underserved market segments. Teams typically used multiple pathways to fund or finance their projects. These funding and financing pathways included conventional (such as power purchase agreements [PPAs] and leases) and unconventional (such as donations and crowdsource investing) approaches. ${ }^{11}$ Many teams planned to enlist at least some crowdsource donations or investments for their projects. Teams also commonly sought grants, loans, and tax equity (Figure 5). There were far fewer teams that pursued lease or fee structures to support solar projects, such as the Green the Church Red team with projects in California, Maryland, and New York and the Solar Access UpGrade Ohio team. The type of organization (e.g. tax-exempt) along with state policy (e.g. ability to sign a power purchase agreement) shaped the type of financing mechanisms teams pursued.

\footnotetext{
${ }^{11}$ PPAs are either physical or virtual contracts between an LMI household, nonprofit, or other community-serving customer and a third party, where the customer secures the physical or financial rights to the electricity generation and, in some cases, the environmental attributes of the project (Heeter, Bird, and Cook 2018).
} 


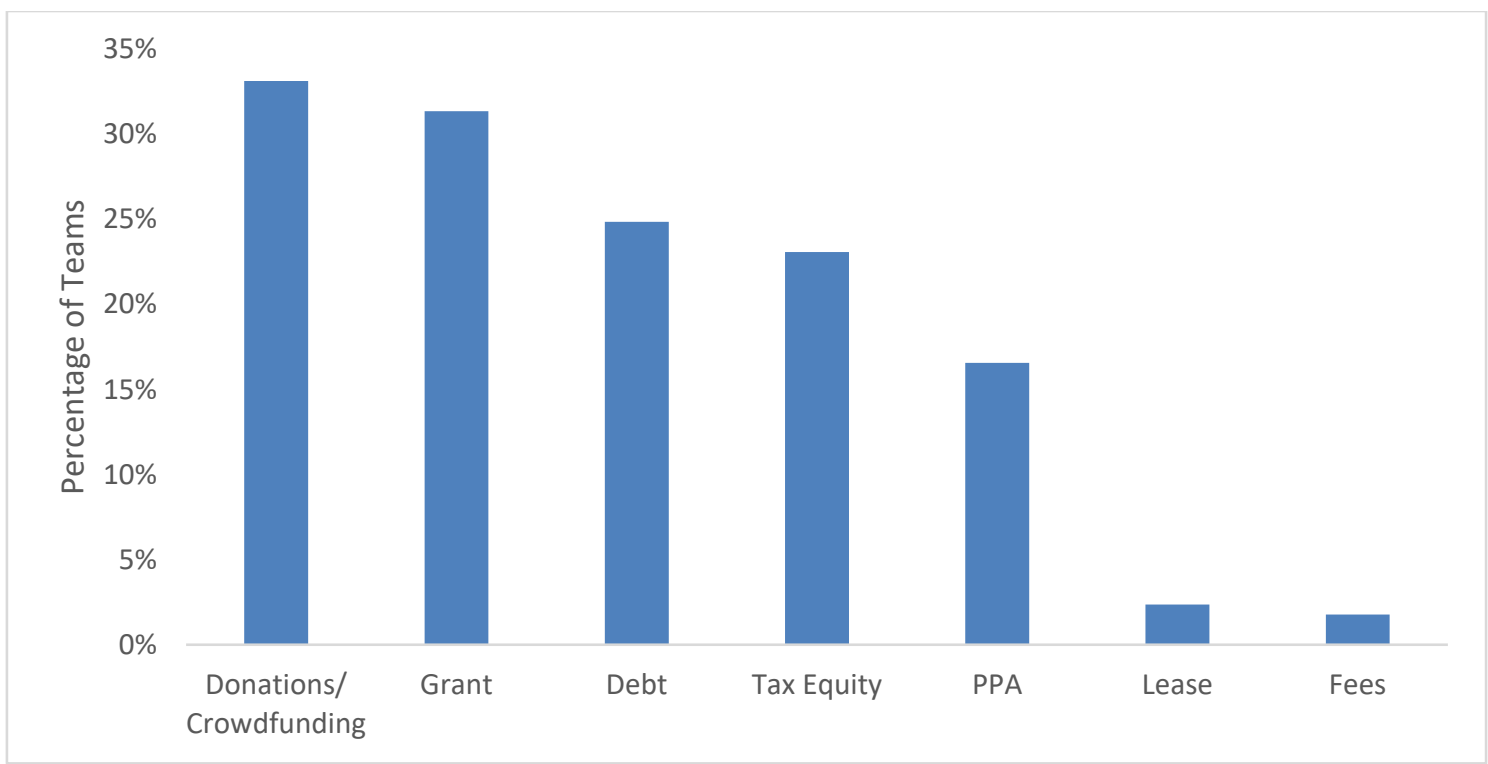

Figure 5. Financing mechanisms used in SIYC Prize Challenge projects

This figure is based on the 113 teams where a financing mechanism was identified based on the team's initial application. 


\section{Key Challenges and Considerations for PV Project Deployment from the SIYC Prize Challenge}

This section provides insights from the questions teams faced when developing their projects. These questions were documented via requests teams made of consultants and perspectives generated from interviewed coaches, consultants, and team members. Based on this data, the section ends with a summary of three barriers and considerations for future projects relating to financing, policy, and legal/business structure.

Teams could select from a set of approved services from consultants in an online TA marketplace. 121 teams were provided TA vouchers and they made a combined 653 TA requests across 14 categories, as summarized in Figure 6.

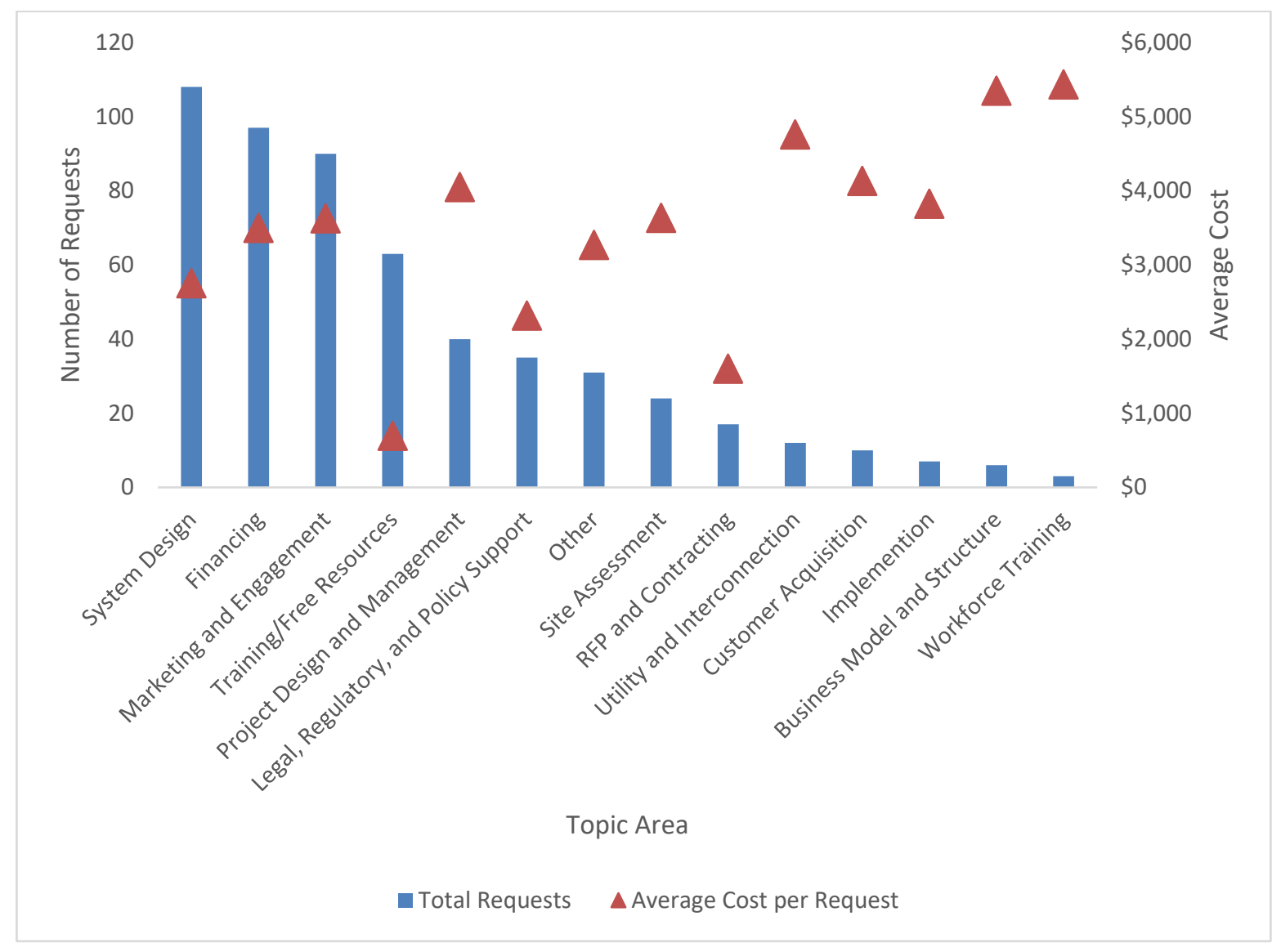

Figure 6. Number of technical assistance requests by type

System design, marketing/engagement, and financing were the three most frequently requested TA topics (Figure 8). On average, teams used between $\$ 2,500$ and $\$ 4,200$ of their allotted funding per request on these services ( $\$ 10,000$ per voucher). In comparison, workforce training, utility and interconnection, and business/legal structure TA requests were some of the least frequently requested topics. However, the teams that did request these services used on average between $\$ 4,700$ and $\$ 5,100$ per request. 
The marketplace requests in Figure 6 represent what teams initially requested from consultants; in some cases, the requests could have evolved from what was originally articulated. To augment this information, interviewees were asked to identify the key technical challenges faced by teams. These perspectives are summarized in Figure $7 .^{12}$

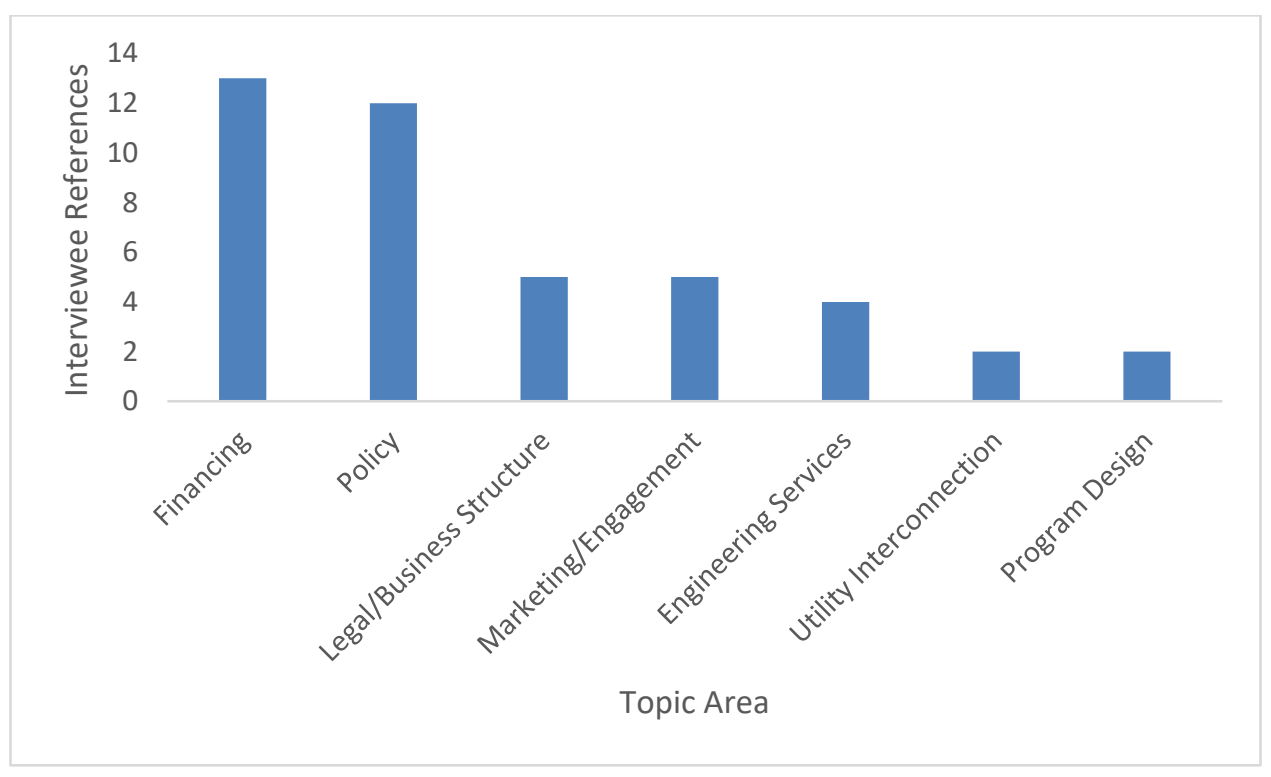

Figure 7. Top challenges identified by interviewees

Financing, policy, legal/business structure, and marketing/engagement were the most commonly identified challenges referenced by interviewees. The perspectives of interviewees are somewhat different than those illustrated by the analysis of the TA marketplace (see Figure 6). Although more teams made system design and marketing/engagement requests in the marketplace, interviewees suggested that financing, policy, and legal/business structure challenges were often more problematic for achieving their goals than system design in particular. This may suggest that while PV system design is important for project development, interested communities may face more challenges with financing, policy, and legal/business structure when carrying out their projects.

Interviewees provided insight on the types of challenges that teams faced in each of these topic areas, along with possible solutions that might be adopted in the future. The remainder of this section summarizes these insights relating to three of the four topics including financing, policy, and legal/business structure. ${ }^{13}$

\footnotetext{
${ }^{12}$ In some cases, interviewees mentioned more than one challenge, and each was counted separately in Figure 7.

${ }^{13}$ Marketing/engagement was excluded because many of these requests were related to developing marketing materials for program or project outreach. Though outreach is an important component of any program, interviewees did not suggest that these requests were tailored to these underserved markets. Rather, the teams were requesting more general marketing/engagement expertise. As a result, less can be gleaned from these marketing/engagement activities specific to future PV projects in these market segments.
} 


\subsection{Financing Barriers and Considerations}

Interviewees identified a few key financing barriers, specifically project size and access to tax equity. Most teams are developing relatively small community or rooftop solar installations. PV projects, especially those less than $100 \mathrm{~kW}$, may be too small to receive competitive power purchase agreement or interest rates. Interviewees suggested this was because there are few financiers that have experience with or have interest in financing small projects. ${ }^{14}$

In addition, many teams were interested in monetizing federal tax incentives through tax equity partners for these small-scale projects. Tax equity structures are complex and can be difficult and expensive to develop. Additionally, there is a limited universe of available tax equity investors and, as a result, less interest and capacity for individual projects or portfolios below a certain value threshold (generally less than $\$ 25$ million) (Feldman and Schwabe 2018). ${ }^{15}$

Interviewees commented that teams developing smaller projects might be more successful identifying financial partners by relying on local community lending or crowdsource donations instead of traditional lending. This approach may also be a more effective means to identify and secure a project partner that can monetize available tax incentives and reduce overall project costs, such as a local private donor or corporate partner.

\subsection{Policy Barriers and Considerations}

Though policy barriers trailed behind financing and other TA requests in the marketplace, interviewees clarified that policy considerations often were incorporated across requests and, in many cases, were central to their assistance to teams. This is because state and local policy influences the types of projects that teams can consider implementing. For example, as of 2018, community solar programs are only offered in certain utility service territories across 35 states (Cook and Shah 2018), and third-party ownership of rooftop solar projects is disallowed or restricted in 9 states and unclear or unknown in an additional 15 states (DSIRE 2018).

According to interviewees, some teams had more limited knowledge of how to apply an innovative concept within their unique policy and regulatory structure. Interviewees noted that teams could have benefitted from first considering what might be possible within their local policy framework prior to considering project specifics such as site feasibility and system design. Policy-related challenges may still arise as projects unfold. Even so, interviewees asserted that considering policy challenges at the outset can help a team maximize the use of limited resources to achieve their solar objectives.

\subsection{Legal/Business Structure Barriers and Considerations}

Relatively few teams requested legal/business structure TA in the marketplace, yet those that did paid relatively more for these services. In some cases, interviewees posited that assistance was

\footnotetext{
14 These entities may offer traditional loan products but not financing options tailored to solar or renewable energy projects. In general, small "one-off” solar projects can be viewed as uneconomic for traditional financial providers or outside their traditional lending expertise.

${ }^{15}$ Without a tax equity partner to monetize the federal tax incentives, the ultimate cost of energy from a solar project will, all else being equal, generally be higher than it would with tax equity in the financial structure.
} 
needed in developing business partnerships with tax equity investors or other partners to provide financing, and in other cases, they were driven by tax filing or program design considerations.

Given the innovative nature of these teams, there were few existing examples of successful ownership structures that they could easily reference or modify to meet their project needs. Thus, the teams often had to start from scratch and develop their own business or ownership framework. Interviewees suggested that as teams begin to implement their projects, the SIYC Prize Challenge should generate replicable business models that can be adopted elsewhere.

Interviewees suggested that as teams create new models, they should limit the number of parties included in formal project design, ownership, and implementation agreements. This can streamline contract approval processes. In addition, it can help reduce the complexity of contracts, including those describing ownership of assets. 


\section{Profiles of Innovative Teams and Related Market Strategies}

As discussed in Section 3, each of the teams selected for the SIYC Prize Challenge adopted an innovative approach to address challenges to LMI, nonprofit, and other community-serving entities' adoption of PV. This section profiles 10 of these teams and their innovative business models or approaches that could be successfully replicated in other contexts. The 10 teams included in this section were selected after consultation with the SIYC Prize Challenge administrator, DOE personnel, and coaches. The goal of these consultations was to identify 10 teams that demonstrate novel approaches that show potential for replication nationwide. This selection is not associated with decisions around final prize award allocation and does not reflect a short list for those awards.

The teams highlighted in this section demonstrate variation in geography, population, target market(s), and business models. Most of the teams profiled in this section are located in the Northeast and Mid-Atlantic (see Figure 8). The remaining teams are located in Appalachia, the upper Midwest, and Texas. The teams differ in terms of the type and size of the population being served, with some targeting small, rural communities (e.g., Shepherdstown, West Virginia), and others addressing more urban communities (e.g., Brooklyn, New York). Most importantly, the profiled teams are implementing a variety of approaches to serve LMI, nonprofit, or other underserved market segments (see Table 2). Three of the ten teams are focused specifically on LMI households, while four teams focus on LMI households and nonprofits. The remaining three teams focus on nonprofits, municipal governments, or some combination of the three. Finally, each of the teams has adopted a different business model and financing approach to support rooftop or shared solar deployment in the designated market segments. The remainder of this section profiles each team with an emphasis on their approach, success factors, and considerations for replication. 


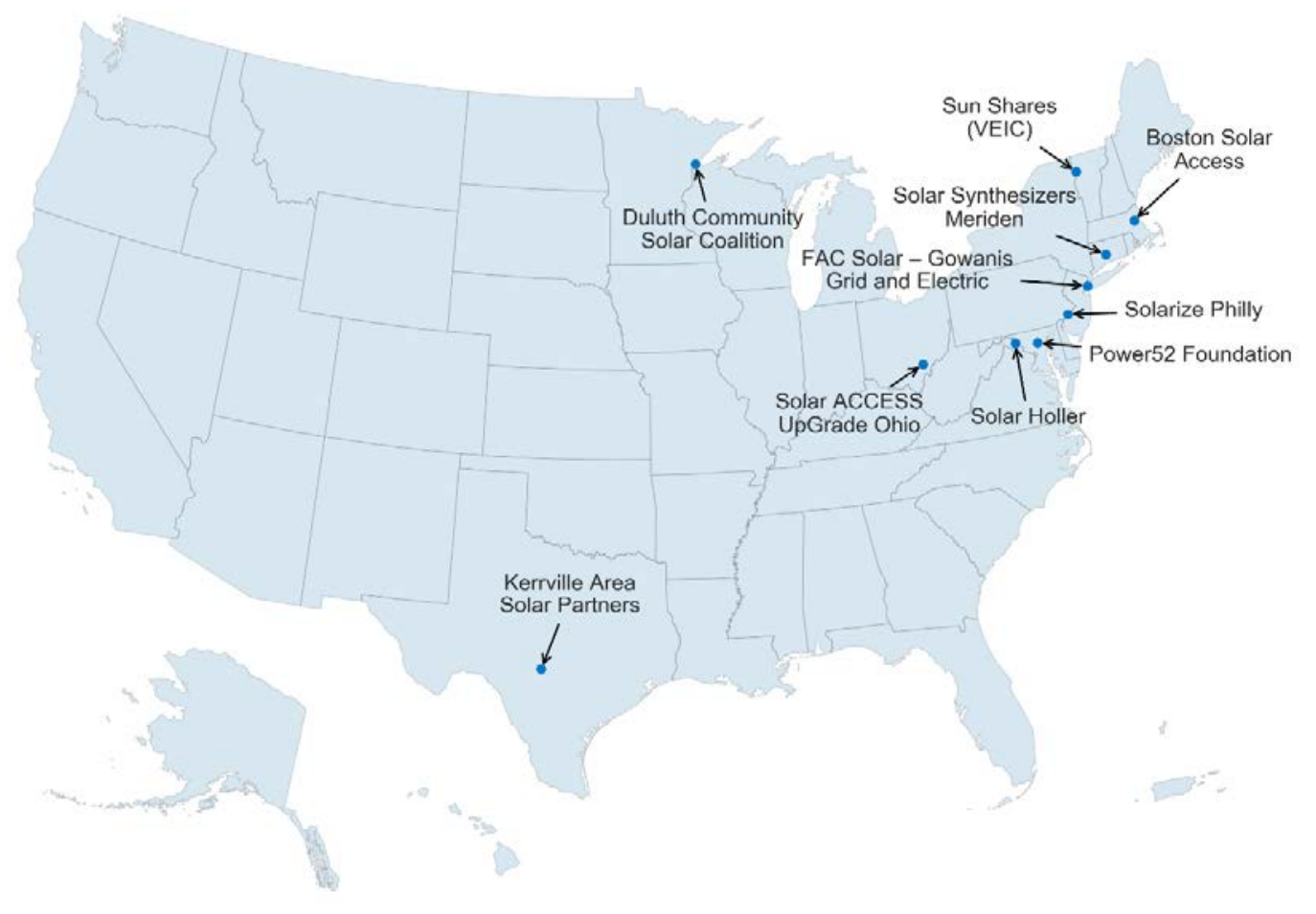

Figure 8. Geographic distribution of profiled teams

This report is available at no cost from the National Renewable Energy Laboratory (NREL) at www.nrel.gov/publications. 
Table 2. Comparison of Profiled Teams by Target Market and Business Model

\begin{tabular}{|c|c|c|c|c|c|c|c|c|c|c|}
\hline \multirow[b]{2}{*}{$\begin{array}{l}\text { Profiled } \\
\text { Team }\end{array}$} & \multirow[b]{2}{*}{$\begin{array}{c}\text { Target } \\
\text { Market(s) }\end{array}$} & \multirow[b]{2}{*}{$\begin{array}{c}\text { Business } \\
\text { Model/Approach }\end{array}$} & \multicolumn{8}{|c|}{ Financing Approach } \\
\hline & & & 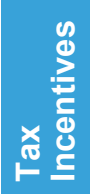 & $\frac{\alpha}{\alpha}$ & 동 & 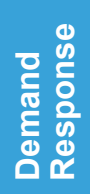 & 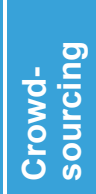 & 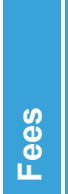 & 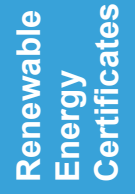 & 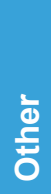 \\
\hline $\begin{array}{l}\text { Boston Solar } \\
\text { Access }\end{array}$ & $\begin{array}{l}\text { LMI households } \\
\text { and nonprofits }\end{array}$ & $\begin{array}{l}\text { Community solar } \\
\text { hosting }\end{array}$ & $\bullet$ & $\bullet$ & & & & & & \\
\hline $\begin{array}{l}\text { Duluth } \\
\text { Community } \\
\text { Solar Coalition }\end{array}$ & $\begin{array}{l}\text { Nonprofits and } \\
\text { municipal } \\
\text { governments }\end{array}$ & $\begin{array}{l}\text { Crowdsource social } \\
\text { impact investing }\end{array}$ & & & & & $\bullet^{a}$ & & & \\
\hline $\begin{array}{l}\text { FAC Solar- } \\
\text { Gowanus Grid } \\
\text { \& Electric }\end{array}$ & $\begin{array}{l}\text { LMI households } \\
\text { and nonprofits }\end{array}$ & $\begin{array}{l}\text { Solar financing for } \\
\text { nonprofit multi-family } \\
\text { housing }\end{array}$ & - & $\bullet$ & & & & & & $\bullet^{b}$ \\
\hline $\begin{array}{l}\text { Kerrville Area } \\
\text { Solar Partners }\end{array}$ & $\begin{array}{l}\text { LMI households } \\
\text { and nonprofits }\end{array}$ & $\begin{array}{l}\text { LMI community solar } \\
\text { rate design }\end{array}$ & - & $\bullet$ & & $\bullet^{c}$ & & & & \\
\hline $\begin{array}{l}\text { Power52 } \\
\text { Foundation }\end{array}$ & LMI households & $\begin{array}{l}\text { Anchor-supported } \\
\text { LMI community solar }\end{array}$ & $\bullet$ & $\bullet$ & & & & & & \\
\hline $\begin{array}{l}\text { Solar Access } \\
\text { UpGrade Ohio }\end{array}$ & $\begin{array}{l}\text { Municipal } \\
\text { governments }\end{array}$ & $\begin{array}{l}\text { Community-choice- } \\
\text { aggregation-supported } \\
\text { solar deployment }\end{array}$ & & & & & & $\bullet^{d}$ & & \\
\hline Solar Holler & Nonprofits & $\begin{array}{l}\text { Workforce training } \\
\text { and place-based } \\
\text { solar deployment }\end{array}$ & & & $\bullet$ & • & - & & $\bullet$ & \\
\hline $\begin{array}{l}\text { Solar } \\
\text { Synthesizers } \\
\text { Meriden }\end{array}$ & $\begin{array}{l}\text { LMI } \\
\text { households, } \\
\text { nonprofits, and } \\
\text { public housing }\end{array}$ & $\begin{array}{l}\text { Low-income-housing- } \\
\text { tax-credit-supported } \\
\text { solar financing }\end{array}$ & $\bullet$ & $\bullet$ & & & & & - & $\bullet^{\mathrm{e}}$ \\
\hline Solarize Philly & LMI households & $\begin{array}{l}\text { Solarize program } \\
\text { fees to support } \\
\text { LMI solar leases }\end{array}$ & • & & & & & • & & $\bullet^{f}$ \\
\hline $\begin{array}{l}\text { Sun Shares } \\
\text { (VEIC) }\end{array}$ & LMI households & $\begin{array}{l}\text { Employer-offered } \\
\text { solar program }\end{array}$ & og & & $\bullet$ & & & & & $\bullet$ \\
\hline
\end{tabular}

a The Duluth Community Solar Coalition team has not developed a project. When they do complete a project, it is possible they will leverage other financing approaches beyond crowdsource donations or investments.

b The FAC Solar - Gowanus Grid \& Electric team also leveraged a state grant.

c The Kerrville Area Solar Partners team is recovering costs for the PPA through customer participation in a unique community solar rate.

${ }^{d}$ The Solar Access UpGrade Ohio team has not developed a project. When they do complete a project, it is possible they will leverage other financing options beyond collected fees such as a PPA.

e The Solar Synthesizers Meriden team also leveraged energy savings performance contracting, property assessed clean energy, and community reinvestment act financing for some of its projects.

${ }^{f}$ The Solarize Philly team uses solarize fees to support leases to LMI participants.

$g$ Only a portion of Sun Shares (VEIC) project was funded by a loan, the remaining financing is unknown though it is expected that available tax incentives were monetized. 


\subsection{Boston Solar Access: Maximizing LMI Benefits in Solar Hosting Programs}

The Boston Solar Access team located in Boston, Massachusetts, is focused on increasing the value LMI residents receive from rooftop solar projects under emerging solar hosting models. In typical solar hosting programs, an electric utility pays a property owner for access to install and operate a rooftop solar system. The utility then controls the rights to the output of the PV system, and the property owner receives a monthly lease payment for use of their rooftop (Cook and Bird 2018). The Boston Solar Access team took a different approach, in which the solar systems are owned by a third-party financier instead of the utility. In addition, project hosts receive a lease payment for the rental of their roof space along with some virtual net metering generation credits from the system's generation, thereby reducing or offsetting LMI and nonprofit energy costs

\begin{tabular}{ll} 
& $\begin{array}{l}\text { Boston Solar Access } \\
\text { Summary Profile }\end{array}$ \\
\hline $\begin{array}{l}\text { Market } \\
\text { Segment(s) }\end{array}$ & $\begin{array}{l}\text { LMI individuals and } \\
\text { nonprofits }\end{array}$ \\
\hline LMI Participants & $\begin{array}{l}10 \text { households and } 8 \\
\text { nonprofits* }\end{array}$ \\
\hline Project Size & 263 kW DC \\
\hline Project Type & Community solar \\
\hline $\begin{array}{l}\text { Business } \\
\text { Model/Approach }\end{array}$ & Community solar hosting \\
\hline $\begin{array}{l}\text { Location } \\
\text { Population }\end{array}$ & Boston, Massachusetts \\
\hline $\begin{array}{l}\text { * The team expects } 12 \text { additional households and } \\
\text { 19 nonprofits to participate in the program through } \\
2019 .\end{array}$ \\
\hline
\end{tabular}
(Resonant Energy 2017a).

In this model, the solar projects are installed on LMI homes and on nonprofits. The solar developer sets up a PPA with a local "anchor institution," typically a creditworthy nonprofit, for $80 \%$ of the generation (see Figure 9). The remaining $20 \%$ of the generation is credited to the project host providing between $10 \%$ and $30 \%$ electric bill savings (on average, about $\$ 360 /$ year) with no accompanying upfront costs, ongoing payments, or credit score requirements (Resonant Energy 2017b). To reduce the cost of the PPA, relevant tax incentives are monetized by social impact investors ${ }^{16}$ identified and aggregated by project partner Sunwealth, a clean energy investment firm. ${ }^{17}$ To date, interviewees commented that the program has installed $263 \mathrm{~kW}$, which includes projects at $10 \mathrm{LMI}$ households and 8 nonprofit hosts. ${ }^{18}$ The team has contracts signed to add an additional 12 LMI households and 19 nonprofit hosts to the program in 2019, with expected capacity totaling $890 \mathrm{~kW}$.

\footnotetext{
${ }^{16}$ These types of investors are interested in supporting projects with social benefits that also provide a financial return that may be lower than traditional investments.

${ }^{17}$ For more information on Sunwealth, see: https:/www.sunwealth.com/.

18 These nonprofit hosts have systems installed on their own property and are distinct from the anchor institutions supporting the LMI household projects.
} 


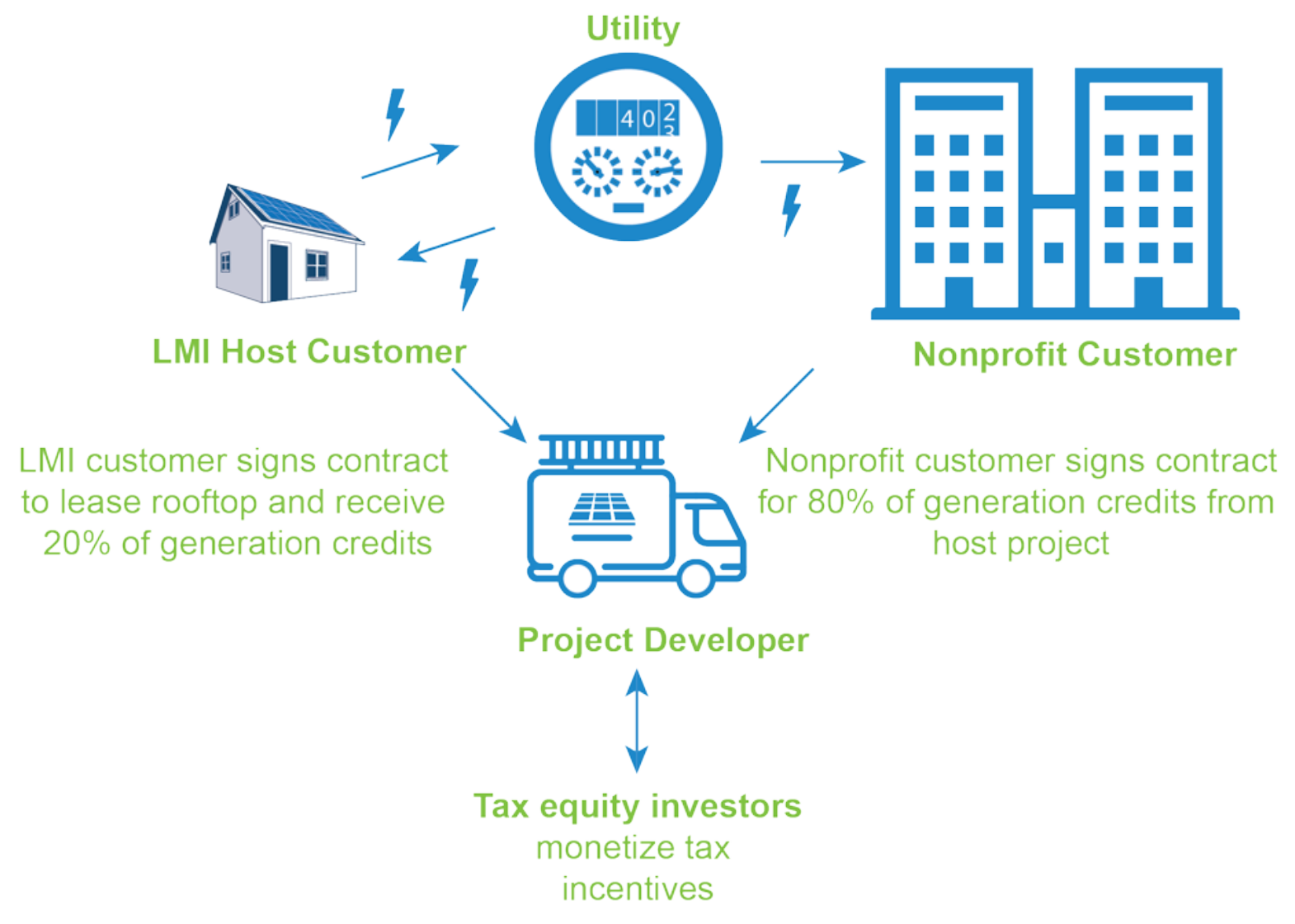

Figure 9. One example of Boston Solar Access program structure

\subsubsection{Contributors to Success}

Interviewees identified a range of factors that have contributed to the success of this team, including adequate state policy, access to social impact investors, and data on housing stock roof age. The program is successful in Massachusetts, given that state policy allows for virtual net metering and this type of solar hosting to qualify as a community or shared solar project.

The team was able to reduce the cost of the PPAs by securing funds from social impact investors that could monetize the solar tax incentives, including the business investment tax credit (ITC) and accelerated depreciation (U.S. Department of Energy 2018). The team also had ease of access to these investors through their partnership with Sunwealth, which aggregates these investors and connects them with project developers such as the Boston Solar Access team. Sunwealth's ability to reduce the transaction costs for these investments by aggregating funds from multiple investors into a single tranche helped reduce PPA prices and maximize savings for LMI residents.

Finally, LMI residents are more likely to reside in older housing with roofs that may need to be replaced prior to installing solar. Identifying homes with relatively new roofs can be challenging, and the team was able to reduce customer acquisition costs by leveraging digital permitting data provided by the City of Boston. This helped the team overlay publicly available median area income data with permitting data to identify potential LMI household leads, thereby reducing customer acquisition and overall project costs. 


\subsubsection{Considerations for Replication}

Though the project was successful, interviewees noted that those interested in replicating this model should consider differences in state policy, roof suitability, electrical permitting requirements, and community interest for future projects.

The team benefitted from a favorable virtual net metering policy where these community solar projects were eligible for generation incentives. Not all states allow virtual net metering or community solar more broadly, and those that do may preclude this type of solar hosting. Some states such as Colorado, Minnesota, and New York require a minimum of 5-10 subscribers to participate in a community solar project (Cook and Shah 2018). Identifying 10 subscribers for LMI rooftop installations increases costs and may not be practical. Determining whether this model will be eligible for existing community solar incentives will be important to determine how much LMI residents may benefit from solar hosting.

Interviewees commented that their access to digital permitting records was helpful for identifying homes with recent roof replacements. A similar digital records system may not be available in many jurisdictions. This may require reviewing permit data by hand or relying on other customer acquisition processes, thereby increasing project costs. If a roof is suitable, interviewees commented that the cost to bring the electrical system of the house to code can also reduce potential LMI customer savings. ${ }^{19}$ Interviewees noted that places like Boston, with old building stock and underground electrical systems, will likely require significant electrical upgrades that should be considered when designing programs. To address this challenge, interviewees suggested that state programs could adopt stipulations similar to those for energy efficiency that provide resources to address these barriers prior to deployment of certain efficiency measures. Absent this type of program, interviewees suggested that social impact investors may also be open to a lower rate of return to accommodate electrical upgrade costs. If not, this model may still work in those cities with newer building stock and fewer electrical upgrade needs.

The Boston Solar Access team, originally called the Cambridge Solar Access team, expected to launch its program in Cambridge, Massachusetts, but eventually shifted to deploy the bulk of their systems in Boston. Interviewees noted that this was due to substantially greater interest from nonprofits and members of LMI communities to support the program in Boston. Future developers might engage with stakeholders, including longstanding nonprofits, residents, and municipal personnel, upfront to ensure they will be willing and supportive partners of the effort.

\footnotetext{
${ }^{19}$ Although roof suitability will ultimately be determined on a case-by-case basis, Sigrin and Mooney (2018) have estimated PV potential, accounting for some building characteristics, including building age, that can help project developers identify census tracts with higher densities of potentially suitable buildings.
} 


\subsection{Duluth Community Solar Coalition: Crowdsource Social Impact Investing}

The Duluth Community Solar Coalition was established in Duluth, Minnesota, with the intent to connect local social impact investors with nonprofit and governmental entities pursuing solar projects. The team developed an online web portal managed by Lake Superior Solar Finance LLC (LSSF) to link these investors with potential projects, while avoiding cumbersome U.S. Securities and Exchange Commission (SEC) regulatory processes (Lake Superior Solar Finance 2018).

For projects to be published on the LSSF portal, they must be compliant with the MNvest Securities Registration Exemption (MN Commerce Department 2018). In 2015, the Minnesota state legislature enacted House File 3 to allow residents to invest in certain businesses

\begin{tabular}{l|l}
\multicolumn{2}{c}{$\begin{array}{r}\text { Duluth Community Solar Coalition } \\
\text { Summary Profile }\end{array}$} \\
$\begin{array}{l}\text { Target } \\
\text { Market(s) }\end{array}$ & $\begin{array}{l}\text { Nonprofits and municipal } \\
\text { governments }\end{array}$ \\
\hline LMI Participants & TBD $^{*}$ \\
\hline Project Size & TBD $^{* *}$ \\
\hline Project Type & TBD $^{* *}$ \\
\hline Business & Crowdsource social impact \\
Model/Approach & investing \\
\hline Location & Duluth, Minnesota \\
\hline Population & 86,066 \\
\hline
\end{tabular}

* Direct LMI participants are not the focus of this program.

** The first project has not yet been announced on the portal. without being subject to SEC regulations (Revisor of Statutes 2018). If the solar project complies with all requirements of the exemption, LSSF will host the project on its portal and interested Minnesota-based investors can review projects, review their rate of return, and invest (see Figure 10). If the project achieves its minimum capital investment goal, the project developer can access the capital and begin implementation. If not, all investors are refunded. The portal is publicly available, and interviewees expect the first project to be published in early 2019.

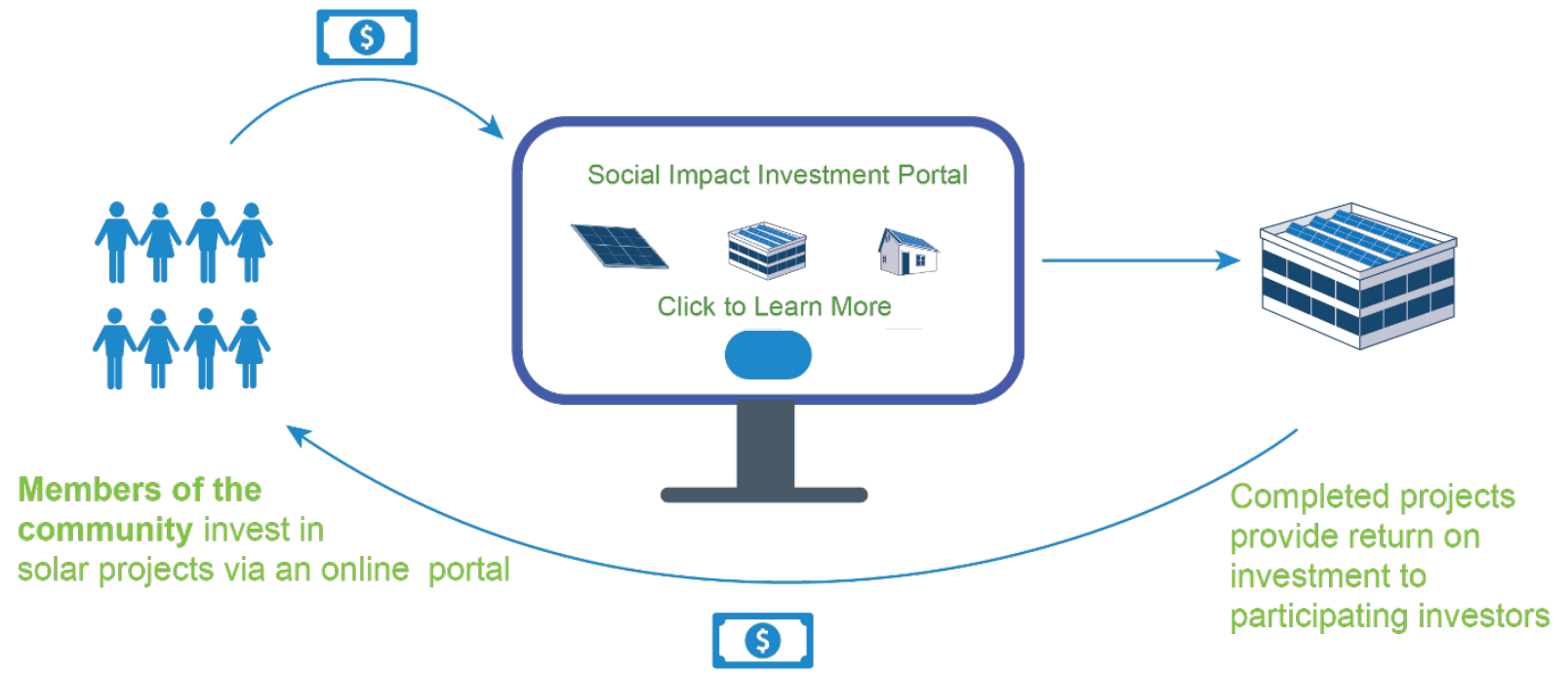

Figure 10. Duluth Community Solar Coalition program structure 


\subsubsection{Contributors to Success}

As of January 2019, no project has been completed through the portal. Even so, interviewees provided some perspectives on what has contributed to their success to date, including state crowdfunding policy, the team's expertise, and its flexible financing model.

Interviewees noted that the state's MNvest law and related guidance lays out a clear path for state residents to invest in businesses without being concerned about SEC regulations. In addition, interviewees commented that the MNvest process can help social impact investors understand the commitment of project developers because it can take significant time and resources to qualify for the MNvest exemption and be included in the LSSF portal.

Given the complexity of the MNvest law, an interviewee asserted that the team also benefitted from expertise within the team relating to the law and its requirements. Even with this internal expertise, the team sought additional TA to ensure that LSSC complied with the law as a portal manager, including its approval process for specific projects.

Finally, the flexible crowdsource investment platform allows for investors to participate as equity or debt investors. Those investors that can monetize relevant tax credits, such as the ITC, can elect to do so as tax equity investors. Others can participate as debt investors. ${ }^{20}$ This flexibility expands the potential pool of investors that can participate while providing them with different investment options and rates of return.

\subsubsection{Considerations for Replication}

There are some emerging considerations for adopting a similar approach elsewhere relating to state crowdfunding policy, project approval processes, and investor interest. Minnesota is one of a few states that provide legislative guidance on how solar project developers can seek crowdsource investment from in-state residents. This model may be more difficult to replicate in states that have not developed similar guidance. Even with this guidance, interviewees attested that setting up the portal and approving projects has been a complex and time-consuming process. These processes can influence the portal's ongoing operation and maintenance costs. Interviewees suggested that as first-generation solar projects get approved using this model, it may reduce these costs on a per-project basis.

Finally, interviewees noted that receiving enough investment to begin the project is not a given, and project developers should consider the potential level of local investor interest prior to listing a project on the portal. On this front, interviewees asserted that project developers should solicit interest from community investors that are already supportive of their missions and then use the portal as an avenue for these and other interested parties to invest and receive a rate of return from the project. If project developers do not have a sense of what types of investors may be interested in a project, it may be more difficult to ensure that the project reaches its investment capital goal.

\footnotetext{
20 These investors essentially loan capital to the project and receive a return via interest payments on their investment.
} 


\subsection{FAC Solar-Gowanus Grid \& Electric: Unlocking Nonprofit- Owned Multi-Family Housing for PV}

The Fifth Avenue Committee (FAC) SolarGowanus Grid \& Electric team is based in Brooklyn, New York, with a mission to find innovative methods to support PV deployment at nonprofit-owned multi-family housing. The team has secured financing for $400 \mathrm{~kW}$ of rooftop community solar distributed across 18 sites owned by the nonprofit FAC, which has a portfolio of 46 buildings across New York City (Paulos 2018a). The electricity generated from the projects will be used to offset both common area and direct tenant load, providing an average of $15 \%$, or approximately $\$ 10 /$ month, in electricity bill savings for residents (Paulos 2018a).

\begin{tabular}{|c|c|}
\hline \multicolumn{2}{|c|}{$\begin{array}{c}\text { FAC Solar-Gowanus Grid \& Electric } \\
\text { Summary Profile }\end{array}$} \\
\hline Target Market(s) & $\begin{array}{l}\text { LMI residents in multi- } \\
\text { family housing }\end{array}$ \\
\hline LMI Participants & 300 households \\
\hline Project Size & $400 \mathrm{~kW}^{*}$ \\
\hline Project Type & Rooftop community solar \\
\hline $\begin{array}{l}\text { Business } \\
\text { Model/Approach }\end{array}$ & $\begin{array}{l}\text { Solar financing for } \\
\text { nonprofit multi-family } \\
\text { housing }\end{array}$ \\
\hline Location & Brooklyn, New York \\
\hline Population & 2.649 million \\
\hline
\end{tabular}

In this model, FAC serves as the leaseholder for the rooftop PV systems, while third-party investors pay for this system and monetize the ITC. ${ }^{21}$ The solar developer, Gowanus Grid \& Electric, signed individual PPAs with each of the FAC facility operating companies that own and manage the buildings (see Figure 11). Gowanus Grid \& Electric operates as the project service company managing allocation, distribution of solar benefits, and monetization of the on-bill solar credits. Gowanus Grid \& Electric then provides FAC facility managers and tenants with reduced electric bills that reflect the bill credits generated from their participation in the project. Contracts with residents are month-to-month and can be transferred to new residents when a participant moves.

${ }^{21}$ The project also received a grant from the New York State Energy Research and Development Authority. 

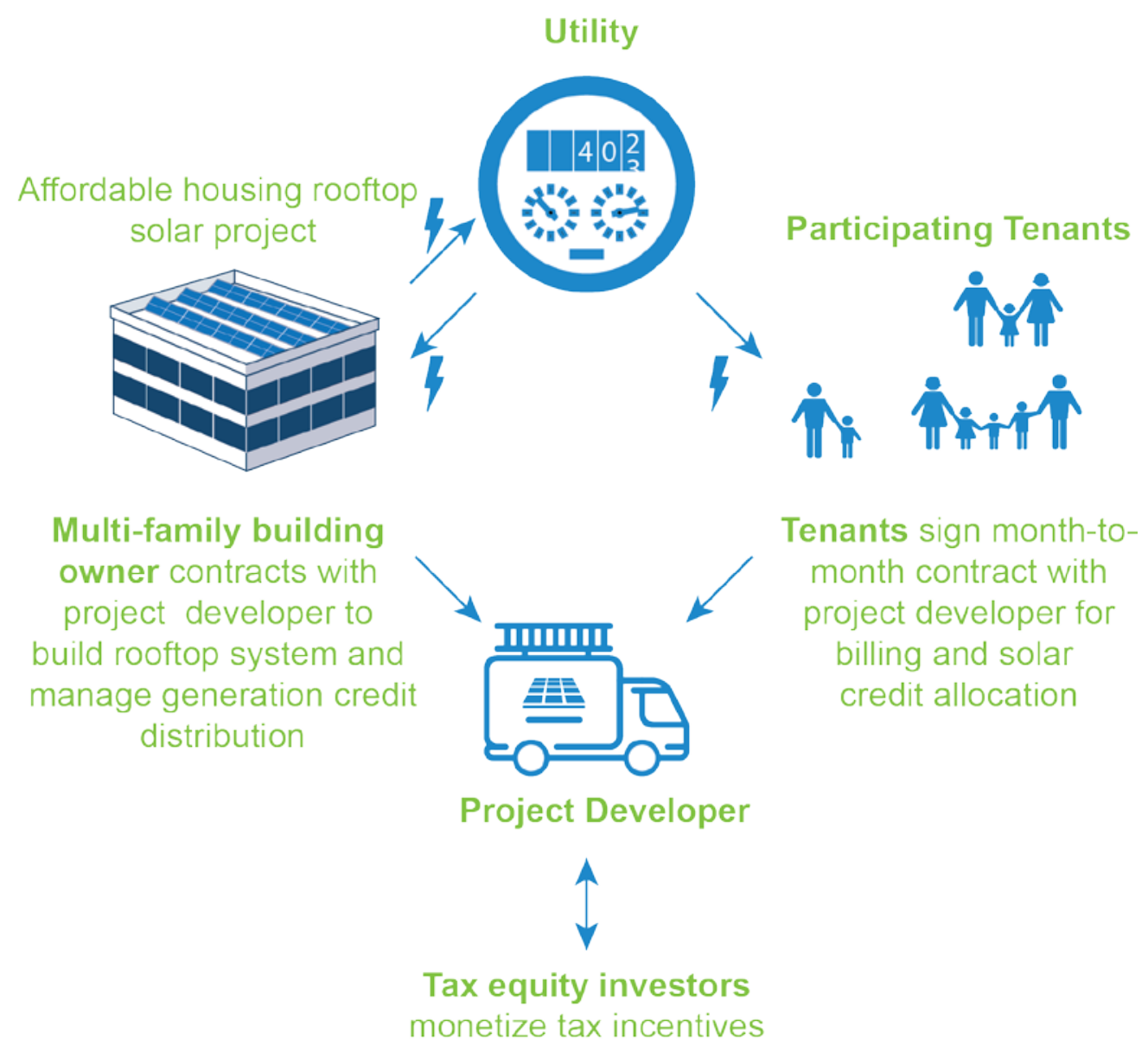

Figure 11. FAC solar project structure

\subsubsection{Contributors to Success}

According to interviewees, this project's success has been driven by the commitment and vision of FAC, the availability of code-compliant technology, and favorable financing and metering arrangements.

According to one interviewee, the commitment of FAC to both deploy solar and provide benefits directly to tenants was important in ensuring the project was implemented as designed. In addition, most of the facilities included in the project have flat roofs, which produced a technology challenge because local fire code requires a 6-foot-wide and 9-foot-high unrestricted roof path (Baldwin 2018a). The team was able to rely on a novel solar canopy design that meets this and other code stipulations (Nonko 2018). An interviewee noted that although this system configuration comes at a higher cost than traditional PV systems, the additional cost still rendered the systems cost-effective at all the selected sites, ensuring the projects could move forward.

Finally, each housing unit is individually metered, allowing tenants to benefit directly from rooftop PV systems. In addition, the financing structure for each of the affordable housing properties allowed tenants to retain the benefits they received from the solar credits without 
having to adjust rent as might be the case for some housing subsidized by the U.S. Department of Housing and Urban Development or other agencies. ${ }^{22}$

\subsubsection{Considerations for Replication}

Successfully adopting this model elsewhere may be impacted by state and local policy, nonprofit housing ownership and financing structures, and developing billing and payment structures that match the market. Interviewees noted that the team benefitted from state policies allowing virtual net metering or community solar. Even so, the team still faced challenges navigating these state policies to achieve their objectives. One interviewee noted that it was difficult, though not impossible, to deploy small community solar projects with fewer than 10 subscribers, which is typically required for the state's community solar program. The team was able to deploy the projects based on exceptions in the regulation, but understanding this policy nuance took time and resources from many team members. In addition, the rooftop community solar projects faced local code barriers that precluded traditional rooftop solar. The team had to elevate the solar panels on canopies to maintain compliance, which could be cost prohibitive in other locations that might have similar code requirements but different solar market considerations (i.e., electricity rates, solar resource, and market maturity). Alternatively, project developers that do not face the same code requirements may be able to provide more PV benefits to participating facility managers and tenants, provided they can install lower-cost rooftop systems.

Though the developer worked with one housing provider, FAC, it still had to develop and sign PPAs with each of the facility's operating companies. Interviewees noted that this required understanding the nuances of the varying ownership structures by facility and designing PPAs that align with each unique structure. This contracting process added time and cost to the project. In addition, some nonprofit housing providers may have more master metered housing stock or may manage federally subsidized housing, which can influence the benefits that tenants might receive from solar projects (Cook and Bird 2018). ${ }^{23}$ Interviewees asserted that it took time and resources to evaluate the financing structure of each facility to ensure tenants would receive the benefits of the solar project. The results of these analyses may not always generate the same favorable results for distributing benefits as articulated here.

Finally, an interviewee noted that most investors prefer automatic direct deposit transactions to reduce uncertainty and risk around debt repayment. Some low-income customers do not use or do not prefer these automatic payment structures. Thus, the project developer had to create alternative customer account management tools to decrease the risk of nonpayment and secure investor participation in the projects.

\footnotetext{
${ }^{22}$ This is most typical for public housing and project-based rental housing that is subsidized by HUD. For more information, see Cook and Bird (2018).

${ }^{23}$ In master metered buildings, tenants pay utilities based on a predetermined method for allocating costs as opposed to actual electricity consumption (Cook and Bird 2018).
} 


\subsection{Kerrville Area Solar Partners: Leveraging Municipal Utility Rate Design to Support LMI Solar Access}

The Kerrville Area Solar Partners team was established in Kerrville, Texas. The team is led by the Kerrville Public Utility Board (KPUB), the community's municipal utility. The team is focused on developing a new pathway to provide low-income residents access to community solar, while at the same time meeting the needs of some of their large nonprofit customers and other ratepayers (Arnold 2017).

To achieve these goals, KPUB procured 3.72 MW of community solar capacity spread across four community projects. Each project is located on land leased from local nonprofits, with three projects interconnected at $0.999 \mathrm{MW}$ each and a fourth at $0.75 \mathrm{MW}$. Interviewees clarified that each project was sized below $1 \mathrm{MW}$ to

\begin{tabular}{l|l}
\multicolumn{2}{c}{$\begin{array}{c}\text { Kerrville Area Solar Partners } \\
\text { Summary Profile }\end{array}$} \\
\hline Target Market(s) & $\begin{array}{l}\text { LMI individuals and } \\
\text { nonprofits }\end{array}$ \\
\hline LMI Participants & $302^{*}$ \\
\hline Project Size & 3.72 MW AC ${ }^{* *}$ \\
\hline Project Type & Community solar \\
\hline Business & $\begin{array}{l}\text { LMI community solar rate } \\
\text { design }\end{array}$ \\
\hline Model/Approach & Kerrville, Texas \\
\hline Location & 23,386 \\
\hline Population & $\begin{array}{l}\text { * Customer count as of October 31, 2018. } \\
\text { * }\end{array}$ \\
** This capacity is split across four projects (three \\
0.999 MW and one 0.75 MW).
\end{tabular}
maximize project savings within the Electric Reliability Council of Texas (ERCOT) market. Interviewees suggested that these projects reduce the utility's wholesale peak load, generating about $\$ 143,000$ in ERCOT transmission cost savings annually. In addition to receiving competitive lease payments, $50 \%$ of the capacity of each community solar project is reserved for the relevant anchor nonprofit (see Figure 12). The remaining 50\% of the project is reserved for low-income residents that live within income-qualified housing (Arnold 2017). As a part of the program, KPUB developed a new rate structure for these eligible low-income residents that passes on the savings a customer might expect on their monthly utility bill. Eligible low-income residents are credited at 8.225 cents per $\mathrm{kWh}(\phi / \mathrm{kWh})$ for the generation of the community solar project, while the cost of generation is $7.073 \notin / \mathrm{kWh}$ (City of Kerrville, Texas 2018). Thus, for each kilowatt-hour credited to the low-income resident, the resident sees a utility bill savings of $\$ 1.152 \phi / \mathrm{kWh}$. This savings is estimated to provide about a $14 \%$ electric utility bill savings each month. 


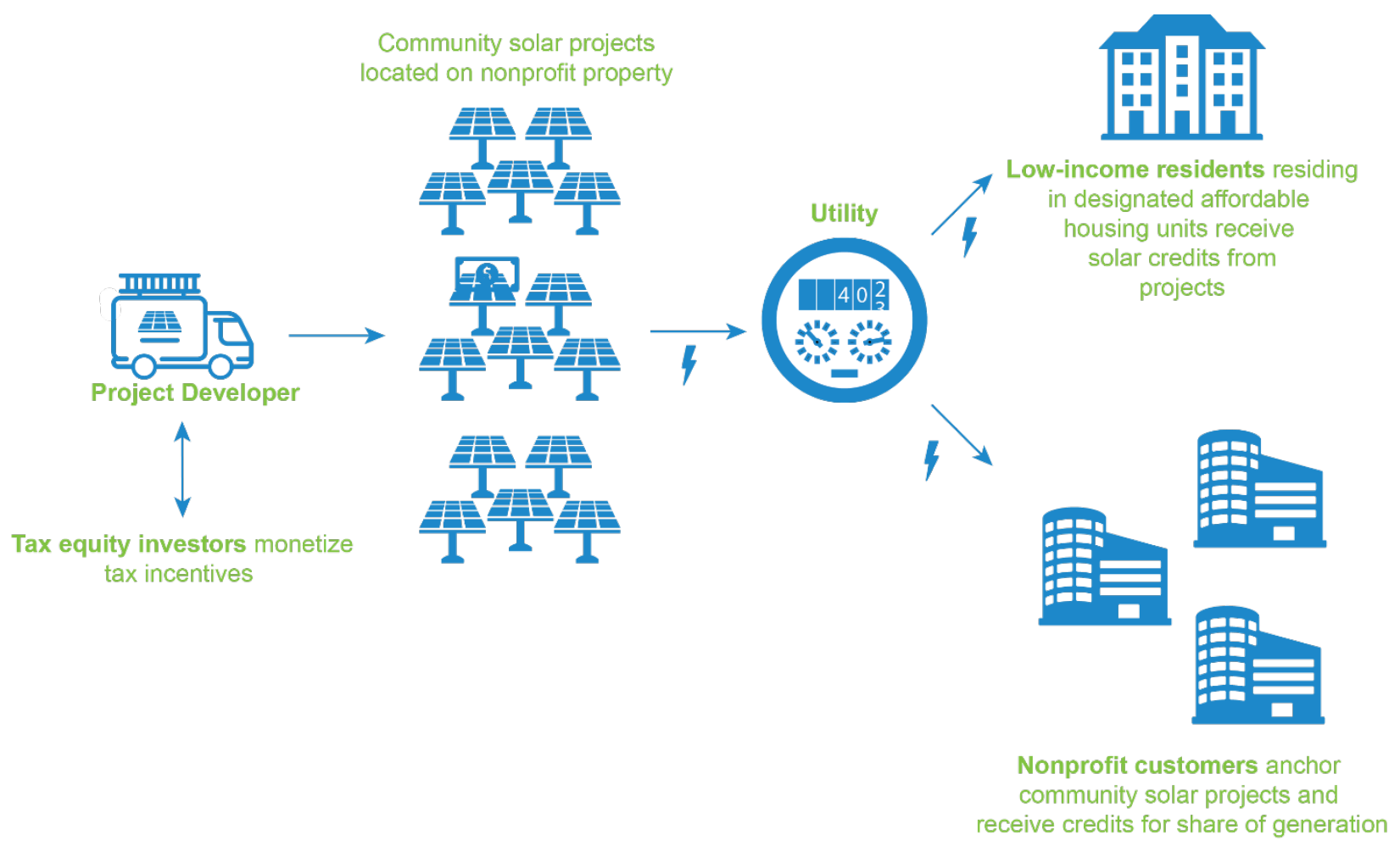

Figure 12. Kerrville Area Solar Partners program structure

\subsubsection{Contributors to Success}

Interviewees identified a set of key factors that were pivotal in the success of this effort relating to project procurement, program administration, and market structure.

Interviewees commented that KPUB was well positioned to serve a key facilitation and procurement role. The utility has long-term relationships with the participating nonprofits who served a critical role as anchor tenants. These anchor tenants can reduce customer acquisition costs, while improving financing terms and the opportunity to mitigate LMI household turnover in projects (Heeter et al. 2018). The utility's energy procurement expertise and its ability to leverage its relationships with nonprofits to negotiate competitive land lease arrangements further reduced project costs.

Interviewees also suggested that KPUB's efforts to simplify program administration was another key factor in keeping overall program costs low. KPUB served as the singular leaseholder and developed one blended rate for all the community solar projects as opposed to separate rate schedules for each nonprofit and participating low-income residents. In addition, KPUB will subscribe low-income customers that live in designated income-qualified housing. This housing will be identified primarily through partnerships with affordable housing providers, including those that have developed LIHTC facilities. This approach minimizes customer acquisition and 
retention costs because the credits will be associated with the income-qualified housing unit, as opposed to the residents that might be tenants in the housing over the life of the project. ${ }^{24}$

KPUB was also able to benefit from market and regulatory structures that incentivize distributed PV or load reductions projects to reduce wholesale peak demand charges. KPUB is located within ERCOT where transmission costs are assigned on KPUB's percentage contribution to the ERCOT summer system peaks. Solar projects with capacity less than $1 \mathrm{MW}$ are not required to register with ERCOT as a generation asset (ERCOT 2018). Rather, the systems appear as load reductions on the ERCOT system, thereby reducing KPUB's contribution to peak load and resulting in transmission savings to the utility on behalf of all customers. Interviewees also confirmed that the project benefits participating nonprofits, low-income customers, and all ratepayers serving as a win-win-win for all parties.

\subsubsection{Considerations for Replication}

Interviewees asserted that their approach could be replicated by other municipal utilities in certain circumstances. Interviewees noted that ERCOT's market design and transmission cost allocation process was important in generating favorable community solar rates. Interviewees believed that other municipal and cooperative utilities could adopt similar projects across ERCOT, while those in other market contexts will need to evaluate regulatory structures with care prior to proceeding.

Limiting project costs was also critical to ensuring low-income residents received a benefit from participation in the project. In this context, interviewees argued that KPUB's relationships with the local anchor nonprofits were important for securing lower-cost financing and competitive land lease rates. Some of these savings could then be passed on to low-income customers through more attractive rates. Importantly, these nonprofits had large land holdings, so they could locate relatively large projects onsite. This partnership structure could be more challenging in urban areas with land constraints or where there are few large corporate customers willing to serve as anchor tenants.

Finally, KPUB was able to work with the solar developer to monetize tax incentives, such as the ITC, that neither the utility nor nonprofits could monetize directly, providing additional financing revenue for the projects.

\footnotetext{
${ }^{24}$ The tenants still receive the benefits directly through credits on their electric bill.
} 


\subsection{Power52 Foundation: Leveraging a Corporate Partnership to Support LMI Community Solar in Baltimore}

The Power52 Foundation leads a team in Baltimore, Maryland, that is committed to reducing low-income residents' energy burden, while providing workforce training opportunities for local residents (Wells 2015a). Power52 owns and operates two private career schools including the Power52 Energy Institute, which offers the Energy Professional Training program accredited by the National Center for Construction, Education, and Research. The program covers the basic concepts of PV systems, as well as system sizing, design, and installation and runs for 16 weeks (McIver 2017). Trainees receive 320 hours of classroom instruction, interactive labs, life skills, job readiness, and on-the-job training (McIver 2017). Approximately $70 \%$ of program graduates have prior criminal convictions on their

\begin{tabular}{|c|c|}
\hline \multicolumn{2}{|c|}{$\begin{array}{l}\text { Power52 Foundation } \\
\text { Summary Profile }\end{array}$} \\
\hline $\begin{array}{l}\text { Target } \\
\text { Market(s) }\end{array}$ & LMI individuals \\
\hline LMI Participants & $\begin{array}{l}\sim 153 \text { residents in the } \\
\text { Cherry Hills neighborhood }\end{array}$ \\
\hline Project Size & $2.5 \mathrm{MW} \mathrm{DC}^{*}$ \\
\hline Project Type & Community solar \\
\hline $\begin{array}{l}\text { Business } \\
\text { Model/Approach }\end{array}$ & $\begin{array}{l}\text { Anchor-supported LMI } \\
\text { community solar }\end{array}$ \\
\hline Location & Baltimore, Maryland \\
\hline Population & 611,648 \\
\hline
\end{tabular}

* $66 \%$ of this capacity is reserved for a Baltimorebased athletic company.

record, and a key goal of the program is to help these individuals attract and retain long-term jobs (Schuh 2018). Interviewees reported that the team has provided 126 individuals with solar development workforce training, boasting an $88 \%$ graduation rate and a $75 \%$ job placement rate. In addition, the team is in the process of deploying a 2.5-MW direct current (DC) community solar project (Power52 2018).

The team has relied on a traditional, subscription-based community solar structure, but the project benefits from an innovative partnership with a Baltimore-based athletic company (Power52 2018). The company serves as the anchor tenant and receives two-thirds of the project's generation. The remaining capacity is expected to reduce energy bills for about 153 subscribed residents in the Cherry Hills neighborhood when completed in 2019 (see Figure 13). This approach allows the corporate partner to benefit from lower and more consistent energy costs, while serving as a strong creditworthy customer to attract private financing in the project. Once the project is constructed, interviewees asserted that individuals from the training program would be enlisted to help complete the project. 


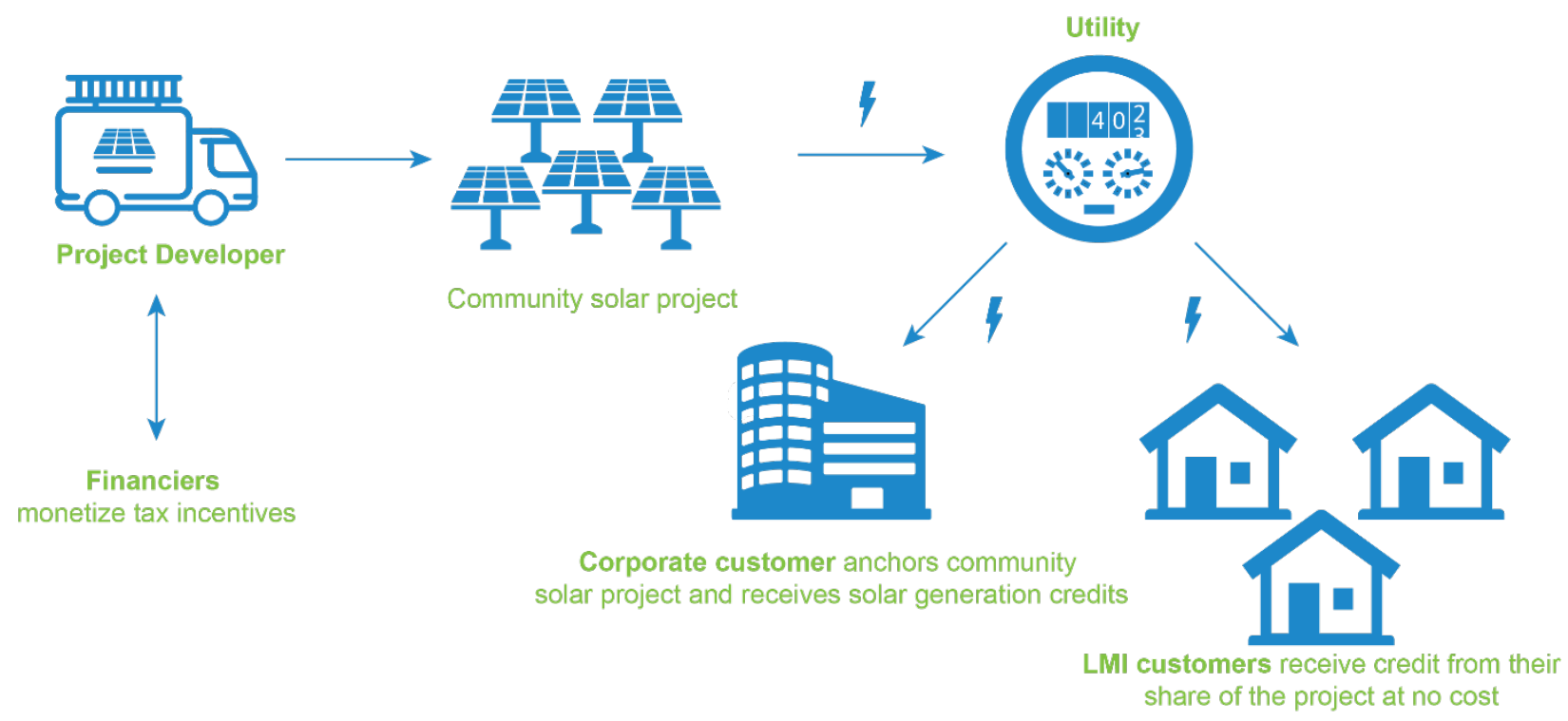

Figure 13. Power52 program structure

\subsubsection{Contributors to Success}

According to interviewees, a variety of factors led to this team's success, including a strong partnership, a local champion, and favorable state policy. The project has benefitted from both a strong team with relevant engineering expertise and strong external partners. The project is located on land owned by Baltimore Gas and Electric, which is the electric service provider for the corporate partner, and the Cherry Hills neighborhood (Power52 2018). The company is another key partner that plays a critical role as a creditworthy off-taker to attract favorable financing terms for project construction.

The project also benefitted from a strong champion, former National Football League player Ray Lewis. Ray Lewis is a co-founder of the Power52 Foundation, and interviewees suggested he played a pivotal role in supporting the low-income resident solar workforce training program and securing the local athletic company as an anchor tenant in the project.

Finally, Maryland has adopted a Community Solar Pilot Program that sets aside about $60 \mathrm{MW}$ for projects focused on LMI customers, including 30.2 MW of reserved capacity in Baltimore Gas and Electric's service territory (Maryland Public Service Commission 2018; Baltimore Gas and Electric Company 2018). This project helps the utility meet its target, and in return, the project receives full retail rate compensation for solar generation, maximizing savings for the company and low-income participants (Wells 2015b).

\subsubsection{Considerations for Replication}

Interviewees suggested that others considering replicating this approach may wish to consider the availability of corporate partners, project champions, and state policy to ensure project success. As noted, a key factor in the success of the project was recruiting the company as an anchor tenant on the project. Other communities interested in this program structure might consider what large corporate customers are headquartered in their community and pursue them as possible anchors to secure favorable financing. In addition, champion Ray Lewis was a key 
player in bringing the corporate partner into the project, and other communities may be more successful if they can secure a similar project champion to reach out to potential partner companies. This project team also benefitted from state community solar policy that incorporates low-income participant requirements along with favorable compensation rates that may not be available in all locations. Despite these limitations, interviewees asserted that this model can be replicated in other locations, and it can provide attractive economic development, corporate responsibility, and social benefits.

\subsection{Solar ACCESS UpGrade Ohio: Deploying Community Solar Through CCAs}

The Solar Appalachian Citizens' Community Economy Solar Shares UpGrade Ohio (Solar ACCESS UPGrade Ohio) team oversaw the implementation of a carbon fee campaign for those residents that participate in the City of Athens CCA program (Baldwin 2018b; Paulos 2018b). ${ }^{25}$ In 2018, city residents approved a measure to adopt an opt-out $\$ 0.2 \phi / \mathrm{kWh}$ carbon fee (Baldwin 2018b). Future revenues collected by the fee will be used to invest in community solar projects developed at certain municipal and school buildings in the City of Athens. The fee is planned to take effect in 2020 (Beard 2018), and interviewees posited it could support up to $60 \mathrm{~kW}$ of rooftop solar annually, potentially providing $\$ 100,000$ in electric bill

\begin{tabular}{l|l}
\multicolumn{2}{c}{$\begin{array}{c}\text { Solar ACCESS UpGrade Ohio } \\
\text { Summary Profile }\end{array}$} \\
\hline Target Market(s) & Municipal governments \\
\hline LMI Participants & $\begin{array}{l}\text { Indirect benefits through } \\
\text { lower municipal energy } \\
\text { costs }\end{array}$ \\
\hline Project Size & TBD* \\
\hline Project Type & Rooftop solar \\
\hline Business & $\begin{array}{l}\text { CCA-supported solar } \\
\text { deployment }\end{array}$ \\
\hline Model/Approach & Athens, Ohio \\
\hline Location & 25,214 \\
\hline Population &
\end{tabular}

* Could support up to $60 \mathrm{~kW}$ of rooftop PV per year. savings each year. These savings will accrue to the city, which can then reallocate dollars to provide additional services to the community (see Figure 14). After successful passage of the measure, the team is now focused on implementing the program and is considering options to expand the carbon fee in the region.

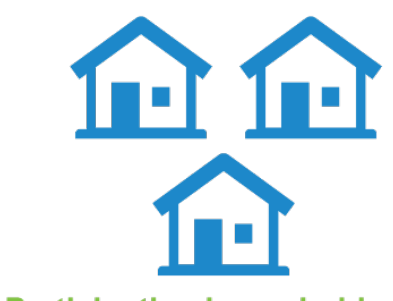

Participating households pay carbon fee to CCA
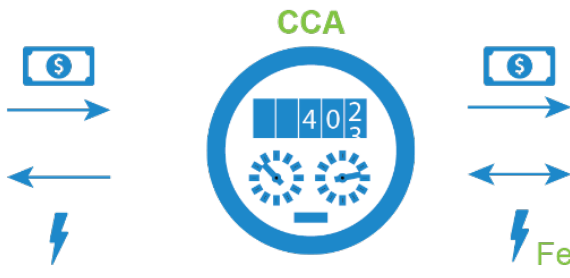

$4_{\text {Fess }}$ and other social service facilities

Figure 14. Solar ACCESS UpGrade Ohio program structure

\footnotetext{
${ }^{25}$ In a CCA, a government entity procures electricity on behalf of retail electricity customers within its jurisdiction
} (O’Shaughnessy, Heeter, and Sauer 2018). 


\subsubsection{Contributors to Success}

Several factors supported the success of this team's approach, including the state's enabling statute for CCAs, alignment with the city's sustainability goals, and a robust engagement strategy. Ohio is one of eight states that allows communities to procure electricity on behalf of retail electricity customers (O'Shaughnessy, Heeter, and Sauer 2018; Lean Energy 2017). The City of Athens has developed a CCA program for city residents who can then opt out of the program and select a different energy supplier. This regulatory model provided the city with the ability to include a carbon fee on willing residents' electricity bills.

The team also sought public buy-in for the carbon fee, and interviewees suggested that the city's long-term commitments to sustainability, including a goal to increase residential and municipal consumption of renewable energy $50 \%$ by 2030 , was a factor in the successful passage of the ballot measure (City of Athens 2017).

Interviewees highlighted the team's robust engagement and information campaign to inform city voters of the details of the initiative and its benefits for the community. One interviewee noted that it was important to clarify that this was not a mandatory carbon tax; rather, it was a voluntary fee and residents could opt out. The team used public forums, social media, and other engagement strategies to clarify this point and highlight the emission and electricity bill savings potential associated with the measure.

\subsubsection{Considerations for Replication}

Though successful in this community, replication elsewhere may be contingent upon regulatory structures that enable CCAs. As noted, only eight states allow CCAs, limiting the opportunity for other communities to adopt this approach. Outside of this regulatory framework, communities served by municipal utilities might be another regulatory structure where city leaders could consider incorporating a similar carbon fee into their rates. If a community can pursue this approach, interviewees commented that the size of the community and the associated fee is a critical element in the viability of it. Smaller communities may have to place higher fees on participating customers to support solar deployment, which could limit public support. Interviewees suggested that one solution would be for communities to work together and pool resources to develop a regional program to address this challenge. This approach can minimize individual bill impacts but may cause additional administrative and implementation challenges. 


\subsection{Solar Holler: Workforce Training and Place-Based Solar Deployment}

The Solar Holler team is headquartered in Shepherdstown, West Virginia, and is committed to deploying solar in this emerging market. The team has championed a solar workforce training program that is integrated with developing place-based solar projects typically at nonprofit and municipal facilities.

In partnership with Coalfield Development, Solar Holler operates the first solar job training and apprenticeship program in West Virginia (Solar Holler 2018). To date, Solar Holler has trained 35 participants, providing 33 hours of paid on-the-job training, 6 hours of community college course work, and 3 hours of life-skills mentorship (Margolis 2017).

Solar Holler enlists these apprentices to help install solar at typically crowdsource-funded projects at public and social service organizations. In 2015, Solar Holler installed a

\begin{tabular}{|c|c|}
\hline \multicolumn{2}{|c|}{$\begin{array}{l}\text { Solar Holler } \\
\text { Summary Profile }\end{array}$} \\
\hline Target Market(s) & $\begin{array}{l}\text { LMI individuals and } \\
\text { nonprofits }\end{array}$ \\
\hline LMI Participants & $35^{*}$ \\
\hline Project(s) Size & $\sim 1 \mathrm{MW}^{*}$ \\
\hline Project Type & Rooftop solar \\
\hline $\begin{array}{l}\text { Business } \\
\text { Model/Approach }\end{array}$ & $\begin{array}{l}\text { Workforce training and } \\
\text { place-based solar } \\
\text { deployment }\end{array}$ \\
\hline Location & $\begin{array}{l}\text { Shepherdstown, West } \\
\text { Virginia }\end{array}$ \\
\hline Population & 1,802 \\
\hline \multicolumn{2}{|c|}{$\begin{array}{l}\text { * This refers only to the } 35 \text { individuals that have } \\
\text { received workforce training. }\end{array}$} \\
\hline \multicolumn{2}{|c|}{$\begin{array}{l}\text { ** This capacity includes constructed and planned } \\
\text { capacity across all Solar Holler projects-not only } \\
\text { those related to nonprofits and municipalities. }\end{array}$} \\
\hline
\end{tabular}
rooftop solar project at Shepherdstown Presbyterian Church, relying on crowdsource funding from 100 community members (Barrick 2015) ${ }^{26}$ These individuals agreed to install demand response controllers on their water heaters by Mosaic Power (Barrick 2015). Mosaic then controls the water heaters to provide grid services, and participants receive $\$ 100$ per year. These individuals agreed to donate these savings to support the solar project loan, providing the system at no cost to the church (see Figure 15). More recently, Solar Holler has installed a variety of solar projects, including one at Harmony House, a nonprofit homeless and social services provider (Pace 2018). Solar Holler initially installed energy efficient lighting, followed by solar, after an anonymous donor contributed $\$ 65,000$ to cover the cost of the solar project (Pace 2018). Employing this place-based model, Solar Holler has about $1 \mathrm{MW}$ of solar in various stages of development with 100 ongoing projects across the residential, commercial, and nonprofit sectors (Clouse 2017; Pace 2018).

\footnotetext{
${ }^{26}$ This project was completed prior to the SIYC Prize Challenge, but this approach could be replicable in other market contexts with similar demand response programs.
} 


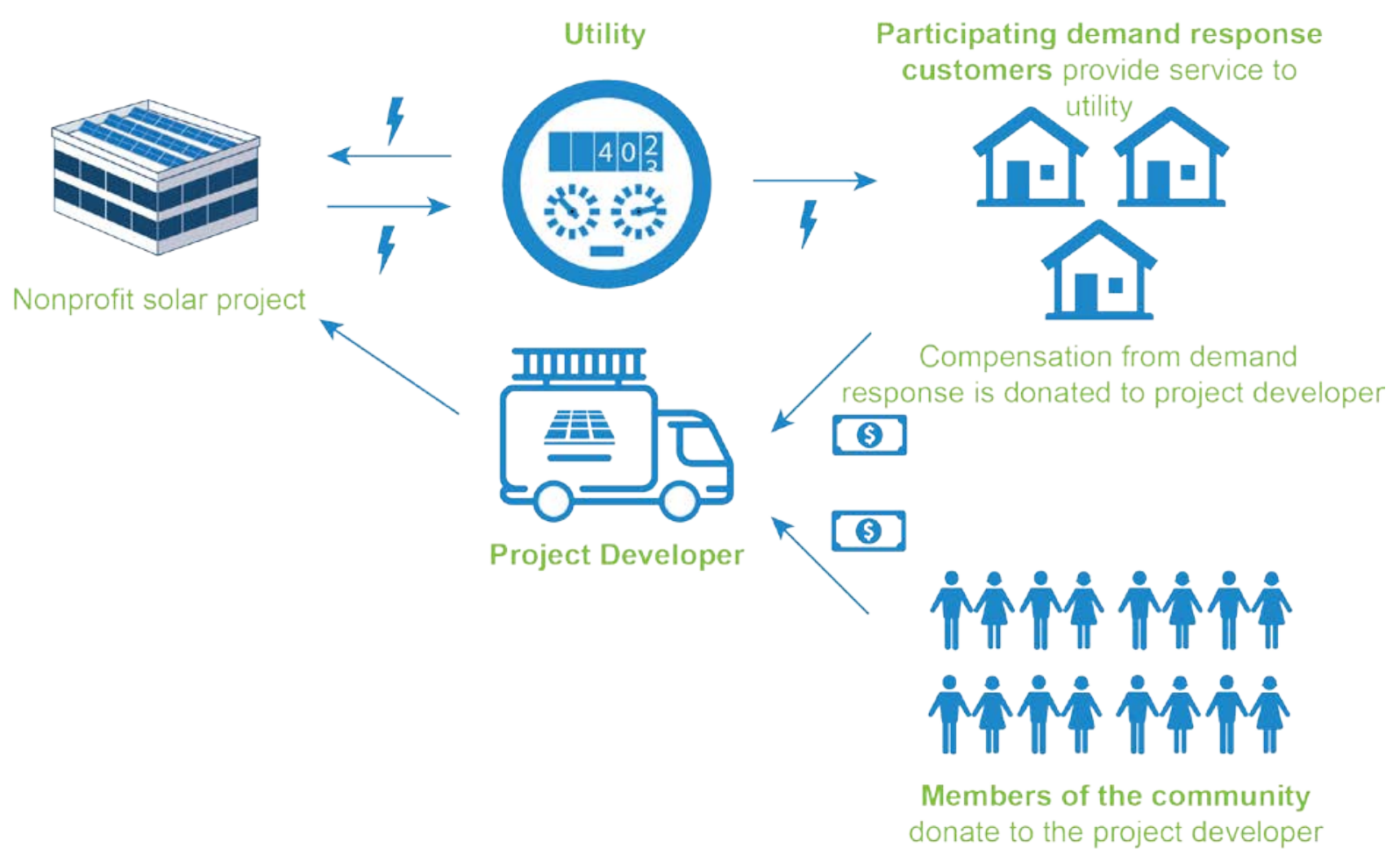

Figure 15. Example Solar Holler project structure

\subsubsection{Contributors to Success}

The Solar Holler team has taken a variety of approaches to support nonprofit and LMI-related solar projects in West Virginia. Interviewees highlighted the value of the solar training program, the team's place-driven business model, and its flexible product/project portfolio as important factors in the team's success.

The West-Virginia-based solar training program has been cited as an important and successful element of the team's approach (Clouse 2017). This training program provides Solar Holler with project installation teams that are then overseen by Solar Holler staff. This approach allows Solar Holler to reduce recruitment and retention needs related to solar projects (Clouse 2017).

Interviewees noted that for many of these projects there has been community support or a willing donor to help finance the project. The team's fundraising success was attributed in part to the team's place-driven business model that was focused on promoting energy development in West Virginia that is affordable to all West Virginians.

Even with supportive funders, interviewees noted that project design and financing will likely vary based upon the unique context of the facility. Given this reality, the team does not provide one financing or project approach but rather tailors their product to each partner's facility. This place-based flexibility allows the team to serve more customers - even those that may be especially difficult cases from a financing or project development perspective. 


\subsubsection{Considerations for Replication}

For teams considering replicating Solar Holler's model, interviewees provided some key considerations relating to utility and state policy, training program design, and business model structure. West Virginia is an emerging market, with relatively low-cost electricity that can make it difficult to deploy solar projects (Clouse 2017). Even so, the team's success illustrates that there are some options to deploy solar, and interviewees highlighted Solar Holler's growth to show that focusing in new markets can be fruitful.

Though interviewees pointed to the training program as a component of the team's success, interviewees also stressed the importance of designing training programs to match the growth of the market. Interviewees noted that training too many individuals may require those individuals to look for work outside of the target region, which may not be the favored outcome, particularly as local markets begin to expand. One option is to cross-train solar installers in energy efficiency measures to help fill gaps between solar projects (Clouse 2017).

Identifying and sustaining funding for similar training programs can be challenging, as demonstrated by funding volatility concerns for workforce training (Margolis 2017). Finally, interviewees pointed to the flexibility and place-based focus of their business model as essential to their success. Fundraising was key for some of their projects, and interviewees noted that this has become easier as Solar Holler has built its brand in West Virginia as a place-driven company focused on reducing energy costs for West Virginians.

Lastly, Solar Holler's willingness to work with partners to find solutions that work for them has helped them build brand recognition in the community. Interviewees suggested that this placebased and flexible approach may be helpful for other teams to have similar success deploying PV projects in other emerging markets.

\subsection{Solar Synthesizers Meriden: Leveraging Low-Income Housing Tax Credits to Support PV Deployment}

Meriden Housing Authority (MHA) partnered with Advanced Energy Group (AEG) to form the Solar Synthesizers Meriden team located in Meriden, Connecticut. The team is focused on providing solar benefits to affordable housing providers and residents and has so far developed two community rooftop solar projects $(229 \mathrm{~kW})$ that provide energy bill savings to 110 households. In 2018, the team added 1.19 MW of additional $\mathrm{PV}$ projects to its pipeline that will serve 371 low-income households (AEG 2017).

This project team has sought several innovative financing options to support PV deployment on behalf of low-income residents in multi-family housing. The first projects relied on traditional

\begin{tabular}{l|l}
\multicolumn{2}{c}{$\begin{array}{c}\text { Solar Synthesizers Meriden } \\
\text { Summary Profile }\end{array}$} \\
\hline Target Market(s) & $\begin{array}{l}\text { LMl individuals and } \\
\text { nonprofits }\end{array}$ \\
\hline LMI Participants & 110 households \\
\hline Project(s) Size & $1.75 \mathrm{MW}^{*}$ \\
\hline Project Type & Rooftop community solar \\
\hline Business & $\begin{array}{l}\text { LIHTC-supported solar } \\
\text { financing }\end{array}$ \\
\hline Lodel/Approach & Meriden, Connecticut \\
\hline Pocation & 59,927 \\
\hline
\end{tabular}

* $229 \mathrm{~kW}$ is already installed capacity. PPA financing to support the installations that provided fewer direct benefits to LMI residents. 
The team's ongoing projects leverage a variety of other more favorable financing approaches, including Property Assessed Clean Energy (PACE), LIHTC, and state grant financing, among others.

This profile describes the team's effort to secure LIHTC funds complemented by financing from other federal incentives, including the ITC and Modified Accelerated Cost Recovery System (MACRS), for a 440-kW roofing-integrated PV system serving 148 low-income households at Yale Acres. ${ }^{27}$ The team submitted the new construction project in the Connecticut Housing Finance Authority's annual competitive LIHTC solicitation. The state then awards the LIHTC allocations to projects based on a set of application criteria. If a project is selected, LIHTC can be used to offset up to $70 \%$ of qualified expenses over a 16-year period (Hefferren 2017). This 440-kW PV project was approved in the 2018 competitive LIHTC solicitation (see Figure 16). MHA is a nonprofit, and the project team secured a third party to monetize available federal tax incentives (ITC and MACRS) covering about $40 \%$ of the cost of the PV installation. These financing streams covered virtually all the expenses to deploy PV at the site, allowing the savings from the PV projects to be used to support low-income household energy bill reduction, providing about $\$ 135$ of bill savings per household in year one. Savings are expected to increase by about 3\% per year over the 25 -year life of the project, providing as much as $\$ 1,500$ in savings by the end of the project.

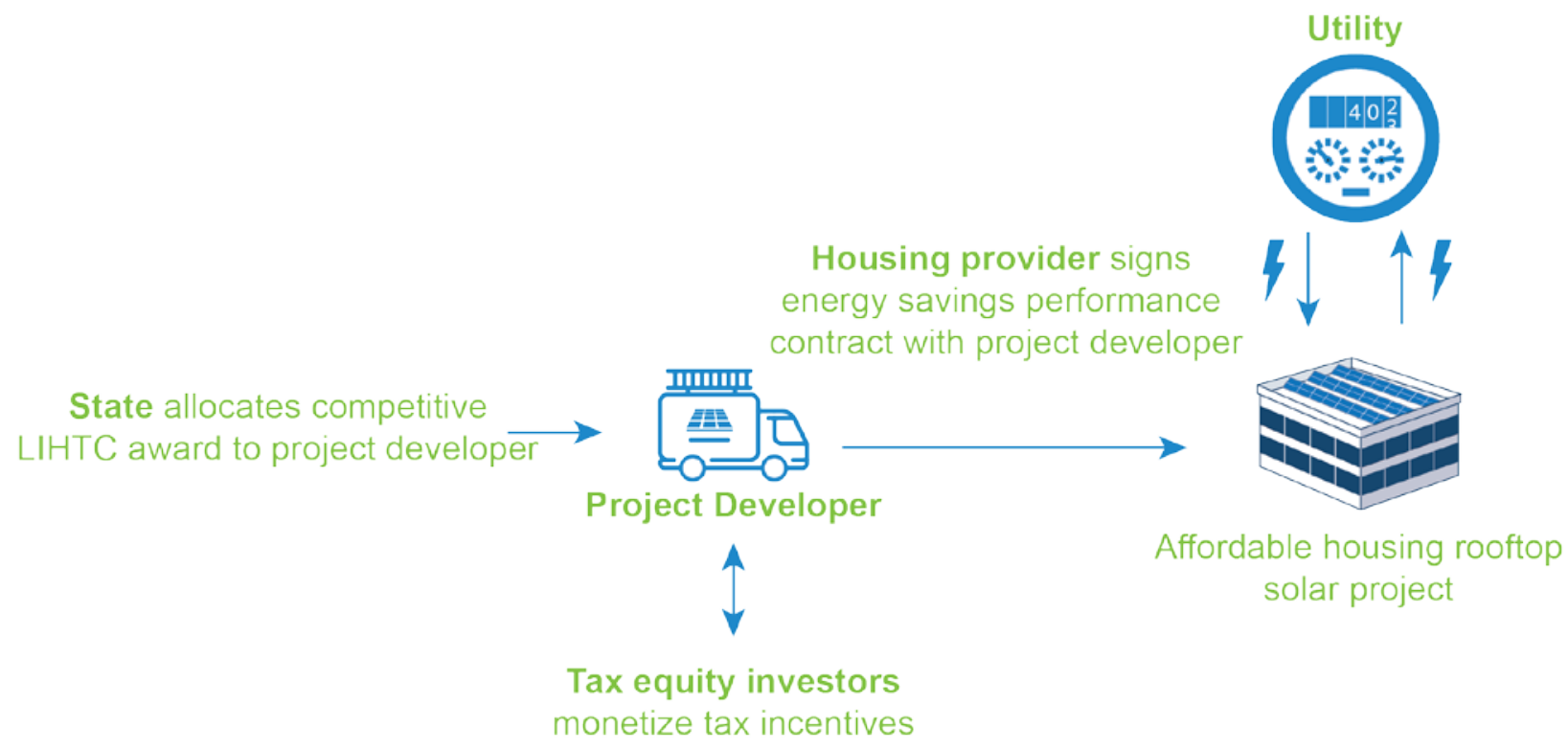

Figure 16. Select Solar Synthesizers LIHTC-supported solar project model

\footnotetext{
${ }^{27}$ For more information on this and other Solar Synthesizers Meriden projects, see: https://aeggroup.wordpress.com/.
} 


\subsubsection{Contributors to Success}

Interviewees asserted that the team was able to succeed given its knowledge of affordable housing financing and compensation structures, favorable state policy, and the emergence of more cost-effective integrated solar and roofing products.

Interviewees noted that the opportunity for affordable housing providers to deploy solar on behalf of low-income residents varies based on the myriad of different affordable housing structures. The team had the relevant expertise to understand the intricacies of affordable housing portfolios and was able to work with providers to find innovative financing approaches that met the different needs of the relevant facilities.

The projects also benefitted from favorable renewable energy credits (RECs) offered by the State of Connecticut for solar projects (NREL 2018). These credits improved the economics of the projects, making them an easier sell to affordable housing providers.

Finally, the team's use of an integrated solar and roofing product was highlighted as a key reason that MHA's solar project was approved in the competitive LIHTC solicitation. ${ }^{28}$ According to interviewees, this approval was based on the fact that the integrated solar roofing product was rated as a 100-year roof, thereby minimizing reroofing requirements over the life of the building. According to this interviewee, the fact that the roof also generates solar was an added benefit but not the driver of the state's approval for its construction.

\subsubsection{Considerations for Replication}

Replicating the success of the Solar Synthesizers team is possible for other affordable housing projects, but interviewees noted that replication will take time, strong knowledge of the intricacies of affordable housing types and financing, and possibly favorable state policy and decisions.

The project team has had long-standing relationships with affordable housing providers and relevant state regulators and has been working with these entities for years to find innovative pathways to deploy solar on affordable housing. This long-term partnership has borne fruit in the form of deployed PV, but developing similar relationships with providers and regulators will take time in other locations.

If providers are interested in deploying solar on behalf of residents, the project team will also need to accurately describe the best pathways for financing solar projects and how solar benefits might be distributed to housing providers and residents.

Finally, the team benefitted from favorable state project incentives and, in at least one case, a competitive LIHTC award. Not all projects may have access to these incentives or win competitive LIHTC awards, influencing the economics of the project.

\footnotetext{
${ }^{28}$ For more information on the building integrated product, see:https://aeggroup.wordpress.com/2018/09/12/aegcontinues-to-make-progress-with-solar-at-yale-acres/.
} 


\subsection{Solarize Philly: Using Solarize Program Fees to Guarantee LMI Solar Leases}

The Solarize Philly team, led by the Philadelphia Energy Authority, took the traditional solar group buy model and modified it to enable participation by LMI customers. The traditional "solarize" campaign bundles procurement of a rooftop solar system within a community, leading to economies of scale for developers and lower costs for purchasers (Cook and Bird 2018).

The Solarize Philly team used this model to lower solar costs and then adopted a small program fee to offset some of the savings to participating solarize customers (Jaramillo 2018; Paulos 2018c). This fee was then used to

\begin{tabular}{l|l}
\multicolumn{2}{c}{$\begin{array}{c}\text { Solarize Philly } \\
\text { Summary Profile }\end{array}$} \\
\hline Target Market(s) & LMI individuals \\
\hline LMI Participants & 45 households (expected) \\
\hline Project Size & $225 \mathrm{~kW}^{*}$ \\
\hline Project Type & Rooftop solar \\
\hline Business & $\begin{array}{l}\text { Solarize program fees to } \\
\text { support LMI solar leases }\end{array}$ \\
\hline Model/Approach & Philadelphia, Pennsylvania \\
\hline Location & 1.581 million \\
\hline Population
\end{tabular}

${ }^{*}$ Assuming each LMI household installs $5 \mathrm{~kW}$. facilitate solar projects on LMI households by guaranteeing payments to the solar developer who loans systems to LMI residents (see Figure 17). As of July 2018, 3,665 individuals had signed up for a free solar assessment, and 232 solar contracts had been signed by participating Philadelphia residents (Rigell 2018; Maykuth 2017). These signed contracts generated \$200,000 in LMIrelated fees. With that funding, the team expects to support an additional 45 LMI solar projects (Jaramillo 2018). Under the solar lease terms, LMI customers will save about $20 \%$ on their electricity bills, or about $\$ 240$ per year. They are not required to put any money down, and the lease runs for 15 years, at which point the homeowner takes ownership of the system with a useful economic life of about 25 years (Rigell 2018). 


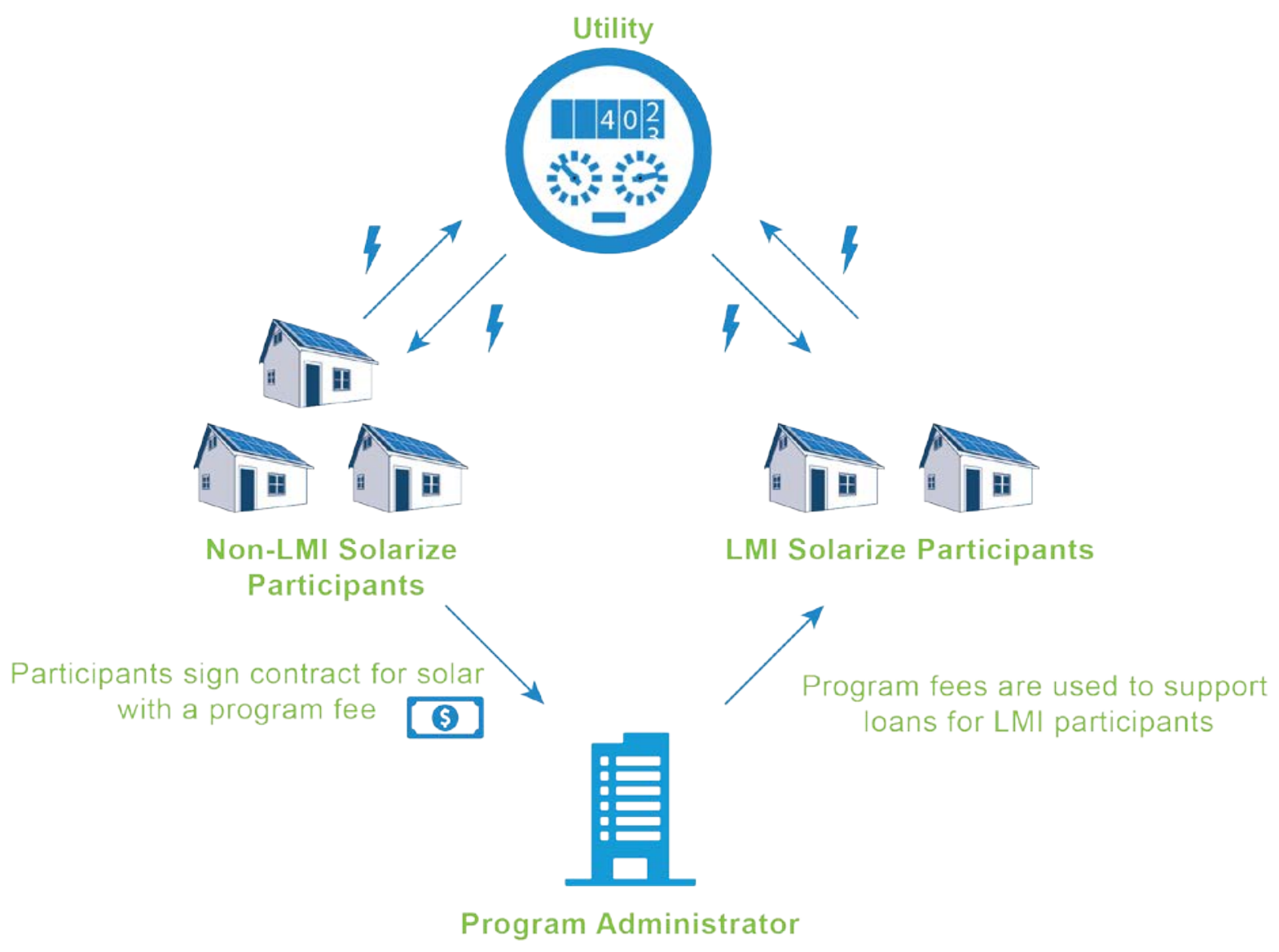

Figure 17. Solarize Philly program structure

\subsubsection{Contributors to Success}

Interviewees concluded that the Philadelphia Energy Authority was poised for success because they had full-time staff, city support, relatively high electricity costs, and coordination with existing social service agencies.

Staff expertise and city support enabled a successful solarize campaign, generating significant signups and enough program fees to develop a non-payment guarantee program. City support may have been advantageous from a customer outreach perspective because residents could have placed more trust in the city government than a private sector company.

Interviewees also noted that the city's relatively high residential electricity costs averaging about $14 \phi / \mathrm{kWh}$ supported higher savings from participating solar customers. Because of this, participants in the solarize campaign were saving money on day one; this makes for a more compelling sales pitch and also enabled the Philadelphia Energy Authority to add a fee to the solar cost while still preserving savings for all solar customers.

Lastly, interviewees noted that the program benefitted by being connected with the city's social support centers, such as those implementing energy assistance programs. This helped identify potential LMI customers to participate in the program. 


\subsubsection{Considerations for Replication}

Interviewees suggested that this successful model can be adopted in other markets relatively easily because there is no need to adjust legal or regulatory frameworks. It also does not need to rely on favorable incentive structures like high solar renewable energy credit markets. Even so, interviewees noted that other solarize programs may face challenges with customer acquisition and projects costs. It remains difficult to find households that meet the criteria outlined in the program: they meet the income guidelines, own their home, have a roof less than 7 years old, and have not missed an electric bill payment (Jaramillo 2018). These challenges persist despite the team's partnership with energy assistance programs, and others considering this approach may face similar challenges. Interest in the program may also be influenced by the value rooftop solar provides to market-rate and LMI customers. Having a solar market where non-LMI customers can save money can make it easier to add on a small program fee to support broader deployment. In addition, having a market where LMI customers can save money from day one makes it easier for program fees to be applied to a non-payment guarantee rather than buying down system costs to support LMI adoption. This latter approach can ensure more LMI customers can participate in the program.

\subsection{Sun Shares (VEIC): Solar as an Employer-Offered Program}

The Sun Shares Vermont Energy Investment Corporation (VEIC) (Sun Shares [VEIC]) team is located in Burlington, Vermont. In this innovative model, VEIC worked with its landlord to develop a $200-\mathrm{kW}$ rooftop community solar project, including a lease for the roof space (Buell 2017). VEIC serves as an anchor tenant for the project, receiving $50 \%$ of the solar project's output. Employees then can subscribe to the other $50 \%$ of the output without individual employee credit checks or upfront payments.

Employees that voluntarily sign up for the program receive $10 \%$ of the credit associated with their share of the project (typically $2 \mathrm{~kW}$ ), and the remaining $90 \%$ of the credit goes back to VEIC to pay for the project (Harringer 2017). Employees receive the full utility bill credit and then VEIC recovers costs through a payroll deduction (Buell 2017; Figure 18). According to interviewees, about 75\% of eligible employees (i.e., reside in Burlington Gas \& Electric's service territory) participate in the program and receive about a $10 \%$ savings on their electric bill (Meehan 2017).

\begin{tabular}{l|l}
\multicolumn{2}{c}{$\begin{array}{c}\text { Sun Shares (VEIC) } \\
\text { Summary Profile }\end{array}$} \\
\hline $\begin{array}{l}\text { Target } \\
\text { Market(s) }\end{array}$ & $\begin{array}{l}\text { LMI households and } \\
\text { nonprofits }\end{array}$ \\
\hline LMI Participants & $\begin{array}{l}18 \% \text { of participating } \\
\text { employees qualify as LMI }\end{array}$ \\
\hline Project Size & 200 kW DC \\
\hline Project Type & Community solar \\
\hline $\begin{array}{l}\text { Business } \\
\text { Model/Approach }\end{array}$ & $\begin{array}{l}\text { Employer-offered solar } \\
\text { program }\end{array}$ \\
\hline Location & Burlington, Vermont \\
\hline Population & 42,239 \\
\hline \multicolumn{2}{|c}{ * Company does not collect income information on } \\
employee subscribers.
\end{tabular}




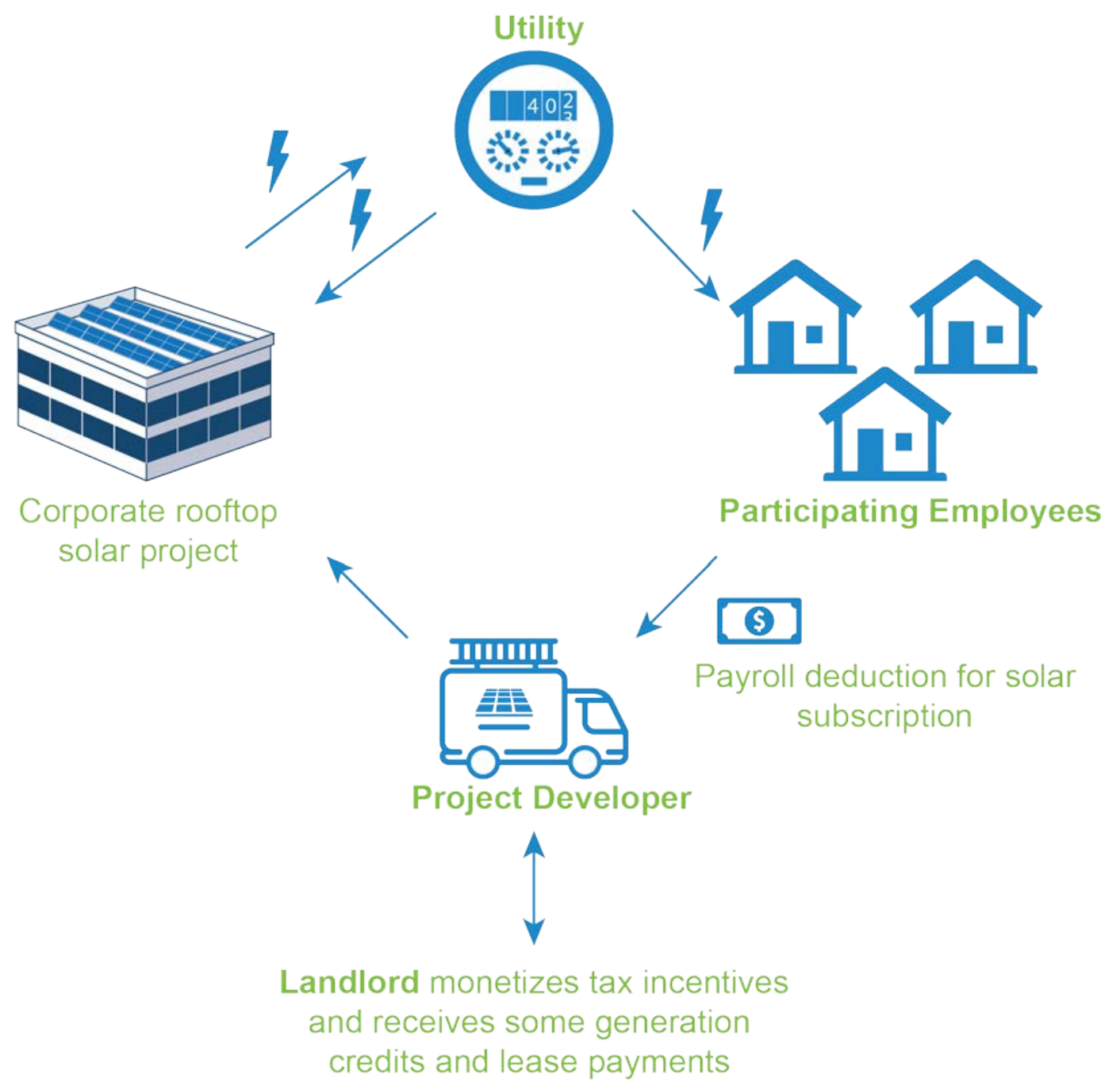

Figure 18. Sun Shares (VEIC) program structure

\subsubsection{Contributors to Success}

Interviewees highlighted several key factors that helped ensure the success of this model, including the involvement of an internal champion, corporate leadership support, a willing landlord, and a competitive, mature solar market.

Interviewees suggested that developing this project was a 2-year process that required significant internal and external negotiations with the property landowner. These negotiations took time, and interviewees posited that without an internal champion these discussions may not have been successful.

In addition, interviewees noted that VEIC leadership provided the team some initial resources to pursue this approach, and this support was important for ensuring the project was implemented. Given VEIC does not own its facility, they were required to work with their landlord to deploy the project. The landlord was ultimately willing to work with the team to develop this project. Interviewees commented that this interest was driven largely by the landlord's tangible benefits 
from the project through monetizing tax incentives, lowering electricity costs, and receiving rooftop lease payments.

Finally, interviewees noted that the mature nature of Vermont's solar market ensured they received competitive prices for solar projects that helped maximize the opportunity for employee bill savings.

\subsubsection{Considerations for Replication}

This successful project offers several considerations for replication relating to project approvals, building ownership structures, credit distribution, and state policy. The negotiation processes took about 2 years to complete, demonstrating the amount of time and related resources needed from the company and the landlord to successfully complete this project. Subsequent projects may be able to reduce these negotiation timelines but not eliminate them. Interviewees suggested that landlords and companies are risk averse, and this project's success may make it easier for others to convince landlords and corporate leadership to adopt similar projects elsewhere. If the company owns its buildings, it can avoid negotiations with a landlord, thereby reducing a significant component of the negotiation process. This can also allow the company to retain more of the benefits from the solar installation, but determining how best to share those benefits, if at all, with employees is up to each individual company. Finally, this approach is predicated on the ability to seek virtual net metering so that credits can be allocated to employees that live off-site. Even in this arrangement, employees must reside within the same electric service territory, which may be problematic when employees live far from the facility and are served by another provider. 


\section{Conclusions}

DOE launched the SIYC Prize Challenge to facilitate new models to support solar in underrepresented markets, namely LMI households, nonprofits, and other community-serving entities. This report summarized some of the key challenges faced by teams in achieving the goals of the SIYC Prize Challenge. In addition, it provided profiles of 10 innovative teams with considerations for how those models may be successfully replicated elsewhere. We conclude with three key takeaways that may be valuable for other communities considering their own solar projects.

Develop a clear understanding of how federal, state, and local policy enable local solar projects. Nine of the ten teams profiled highlighted the important role that enabling policy played in shaping their project structure and financing. The availability of virtual net metering or community shared solar programs was a key factor in enabling 8 of the 10 profiled teams' projects while the Solar ACCESS UpGrade Ohio team benefitted from state legislation allowing CCAs. Policy can also influence financing pathways. For example, the Duluth Community Solar Coalition highlighted the importance of the state's crowdsource investment law. Additionally, the Boston Solar Access, FAC Solar, and Solar Synthesizers teams sought third parties to monetize federal tax incentives on behalf of ineligible clients.

Future solar project teams will need to understand how federal, state, and local policies (e.g., interconnection, third-party ownership) influence the team's target audience, project selection, and financing approaches. In emerging markets where the policy environment may not be clearly defined, teams may need to design projects on a case-by-case basis, as the Solar Holler did. After some of these projects are completed and policy uncertainties are resolved, the team may then be able to build a more replicable approach for the given market segment.

\section{Build durable and long-term partnerships with community members and solar}

stakeholders. These partnerships can ensure that pilot projects are implemented and followed by second-generation projects for more widespread deployment. Each of the profiled teams developed long-term partnerships between some combination of project developers, investors, property owners, utilities, and community organizations, among others. In many cases, these partnerships took time to develop and were driven by committed individuals that played a pivotal role in identifying a target audience, addressing challenges, and securing approval to carry out the project from all relevant parties. Absent these champions, these pilot projects may never have been adopted, making it more difficult to offer blueprints for future projects.

In at least six of the projects, the teams had to secure buy-in or support from LMI household, nonprofit, and property owner partners to implement their projects. For example, Boston Solar Access, Kerrville Area Solar Partners, Power52 Foundation, and Sun Shares (VEIC) all secured large corporate or nonprofit anchor tenants to help reduce customer acquisition, financing, and siting costs. In the case of FAC Solar, Kerrville Area Solar Partners, and Solar Synthesizers, affordable housing providers were not only important partners in deploying the projects but also distributing benefits of the projects to relevant LMI households. This and other partnerships with community organizations can help project developers reduce customer acquisition costs given these groups' access to residents and the higher level of trust between these entities and LMI households. 


\section{Develop a creative portfolio of financing solutions for small and medium sized solar}

projects. Each of the 10 teams used different finance and funding methods, but there were some similarities. Monetizing federal tax incentives was critical across most of these projects; some developers sought third-party tax equity investors to monetize the ITC (e.g., Boston Solar Access, FAC Solar, Kerrville Area Solar Partners, and Solar Synthesizers). Monetizing this credit can finance as much as $30 \%$ of the project. If a team cannot monetize the ITC, it does not mean a project is not financially viable, as exemplified by the Solar Holler team. Teams also used creative solutions including securing anchor tenants, crowdsource philanthropy, compensation from virtual or net metering, or compensation for other grid services (e.g., demand response and load reduction).

Each built stack was impacted by the partners included in the project, the policy landscape, and the project structure. This environment required each team to be flexible and creative in the types of financing they secured. Although building a unique financing stack accounting for these variables can take time, the success of each team demonstrates the range of funding options that might be possible to implement.

Overall, this report provides key insights from a variety of innovative projects that demonstrate that expanding solar access to underrepresented markets is feasible in a variety of markets. Interested communities may wish to use this report as a resource when considering projects and programs to achieve their own energy-related objectives. 


\section{References}

AEG. 2017. Meriden Housing Authority and Advanced Energy Group Join the Department of Energy's Solar in Your Community Challenge. AEG Group.

https://aeggroup.wordpress.com/2017/06/12/meriden-housing-authority-and-advanced-energygroup-join-the-department-of-energys-solar-in-your-community-challenge/

Arnold, Bonnie. 2017. "KPUB to Explore Solar Power with Grant.” Community Journal:

Kerrville's Hometown Newspaper. http://www.hccommunityjournal.com/article_94148d48-fdfa11e6-a20e-db46b4e68688.html

Baldwin, John David. 2018a. New York Solar Canopies Overcome Challenges to Renewable Energy. Solar United Neighbors. https://www.solarunitedneighbors.org/new-york-solarcanopies-overcome-challenges-to-renewable-energy/

Baldwin, John David. 2018b. Turning a Carbon Fee into Solar on Rooftops. Solar United Neighbors. https://www.solarunitedneighbors.org/turning-a-carbon-fee-into-solar-on-rooftops/

Baltimore Gas and Electric Company. 2018. BGE Community Solar Pilot Program. Baltimore Gas and Electric Company.

https://www.bge.com/SmartEnergy/InnovationTechnology/Pages/BGECommunitySolarPilotPro gram.aspx

Barbose, Galen L., Naïm R. Darghouth, Ben Hoen, and Ryan H. Hoen. 2018. Income Trends of Residential PV Adopters: An Analysis of Household-Level Income Estimates. Berkeley, CA: Lawrence Berkeley National Laboratory. https:/emp.lbl.gov/publications/income-trendsresidential-pv-

adopters/?utm_source $=$ newsletter98\&utm_medium $=$ email\&utm_campaign $=$ Constant $\% 20$ Contac $\mathrm{t}$

Barrick, Michael M. 2015. "West Virginia Church Earns Award for Solar Energy Use." Appalachian Chronicle. https://appalachianchronicle.com/2015/04/25/west-virginia-churchearns-award-for-solar-energy-use/comment-page-1/

Beard, Kayla. 2018. "SOPEC Carbon Fee - What Comes Next?" The Athens News. https://www.athensnews.com/news/local/sopec-carbon-fee-what-comes-next/article_f57f7b6056d7-11e8-9601-8f02226f536f.html

Buell, Jeff. 2017. SunShares Demonstrates New Approach to Community Solar. VEIC. https:/www.veic.org/media-room/news/2017/10/05/sun-shares-demonstrates-new-approachcommunity-solar

City of Athens. 2017. Athens Sustainability Action Plan. The City of Athens Environment and Sustainability Commission. https://www.ci.athens.oh.us/DocumentCenter/View/3903/AthensCity-Sustainability-Plan-v10?bidId 
City of Kerrville, Texas. 2018. Ordinance No. 2018-22. Kerrville Code of Ordinances.

https://legistarweb-

production.s3.amazonaws.com/uploads/attachment/pdf/243955/Ordinance_No._2018-22.pdf

Clouse, Carol J. 2017. "Green Energy in a Coal State: The Struggle to Bring Solar Jobs to West

Virginia." The Guardian. https://www.theguardian.com/sustainable-business/2017/mar/19/solarpower-industry-jobs-market-coal-west-virginia

Cook, Jeffrey J., and Lori Bird. 2018. Unlocking Solar for Low- and Moderate-Income

Residents: A Matrix of Financing Options by Resident, Provider and Housing Type. Golden, CO:

National Renewable Energy Laboratory.

Cook, Jeffrey J., and Monisha Shah. 2018. Focusing the Sun: State Considerations for Designing Community Solar Policy. Golden, CO: National Renewable Energy Laboratory.

DSIRE. 2018. $3^{\text {rd }}$ Party Solar PV Power Purchase Agreements (PPA). http://ncsolarcenprod.s3.amazonaws.com/wp-content/uploads/2018/03/DSIRE 3rd-Party-PPA March 2018.pptx

ERCOT. 2018. Distributed Generation. Electric Reliability Council of Texas, Inc. http://www.ercot.com/services/rq/re/dgresource

Feldman, David, and Paul Schwabe. 2018. Terms, Trends, and Insights on PV Project Finance in the United States, 2018. Golden, CO: National Renewable Energy Laboratory.

Harringer, Jennifer. 2017. "New Vermont Company Creates Solar Community Concept.” NBC 5. https://www.mynbc5.com/article/new-vt-company-creates-solar-community-concept/12788687

Heeter, Jenny, Jeffrey J. Cook, and Lori Bird. 2018. Charting the Emergence of Corporate Procurement of Utility-Scale PV. Golden, CO: National Renewable Energy Laboratory.

Hefferren, Neal. 2017. A Complete Guide to the Low-Income Housing Tax Credit Program. Property Metrics. https:/www.propertymetrics.com/blog/2017/06/13/a-complete-guide-to-thelow-income-housing-tax-credit-program/

Jaramillo, Catalina. 2018. Philly Introduces Affordable Route to Rooftop Solar. PlanPhilly. http://planphilly.com/articles/2018/05/22/philly-introduces-affordable-route-to-rooftop-solar

Lake Superior Solar Finance. 2018. Lake Superior Solar Finance: Current Offerings. https://lssf.sppx.io/

Lean Energy. 2017. CCA by State. Lean Energy. http://leanenergyus.org/cca-by-state/

Margolis, Jason. 2017. After Generations Working in Coal, Young West Virginians are Finding Jobs in Solar. Public Radio International (PRI). https:/www.pri.org/stories/2017-09-12/aftergenerations-working-coal-young-west-virginians-are-finding-jobs-solar

Maryland Public Service Commission. 2018. Community Solar Pilot Program. Maryland Public Service Commission. https://www.psc.state.md.us/electricity/community-solar-pilot-program/ 
Maykuth, Andrew. 2017. "Solarize Philly Helps Provide 186 Homeowners with Rooftop Solar Panels." The Inquirer. http://www2.philly.com/philly/business/energy/solarize-philly-provides186-homeowners-with-rooftop-solar-panels-20171205.html

McIver, Terry. 2017. "Power52 Brings Energy Sector Job Training to Urban Communities." Contracting Business. https://www.contractingbusiness.com/learning-resources/power52-bringsenergy-sector-job-training-urban-communities

Meehan, Chris. 2017. "Sun Shares Launches Community Solar at the Workplace in Vermont." SolarReviews. https://www.solarreviews.com/news/sun-shares-launches-workplace-communitysolar-project-101117/

MN Commerce Department. 2018. MNvest. Minnesota Department of Commerce. https://mn.gov/commerce/industries/securities/mnvest//

Nonko, Emily. 2018. "Bringing Solar Power to Affordable Housing in Brooklyn." Next City: Inspiring Better Cities. https://nextcity.org/daily/entry/bringing-solar-power-to-affordablehousing-in-brooklyn

NREL. 2018. Solar Research - Midmarket Solar Policies in the United States: Connecticut. Golden, CO: National Renewable Energy Laboratory. https://www.nrel.gov/solar/rps/ct.html

O'Shaughnessy, Eric, Jenny Heeter, and Jenny Sauer. 2018. Status and Trends in the U.S. Voluntary Green Power Market (2017) Data. https://www.nrel.gov/docs/fy19osti/72204.pdf.

Pace, Fred. 2018. Huntington's largest solar panel project underway. Charleston Gazette-Mail. https://www.wvgazettemail.com/news/huntington-s-largest-solar-panel-projectunderway/article_7ce000f7-7cc8-594e-ad8e-d0f600976c7c.html

Paulos, Bentham. 2018a. "Solar Grows in Brooklyn." PV Magazine. https://pv-magazineusa.com/2018/10/03/solar-grows-in-brooklyn/

Paulos, Bentham. 2018b. "In Ohio Town, Energy 'Locavores' Drive Demand for Community Solar." Energy News Network. https://energynews.us/2018/04/17/midwest/in-athens-ohioenergy-locavores-drive-demand-for-community-solar/

Paulos, Bentham. 2018c. "Philadelphia Finds a New Way to Support Low-Income Solar." PV Magazine. https://pv-magazine-usa.com/2018/07/18/philadelphia-finds-a-new-way-to-supportlow-income-solar/

Power52. 2018. Power52 Energy Solutions: Solar Solutions. Power52 Energy Solutions. https://www.power52energy.com/solutions/

Resonant Energy. 2017a. Solar Access Program. Resonant Energy. https://static1.squarespace.com/static/56fbfd2d37013b142d331d72/t/5ba25b3f898583e210704c4 4/1537366850392/SAP+Information.pdf 
Resonant Energy. 2017b. Cambridge Solar Access Campaign. Resonant Energy.

http://www.greencambridge.org/uploads/8/1/2/0/81204438/170117_cambridge_1_2pg_digital2.pdf

Revisor of Statutes. 2018. 2018 Minnesota Statutes. The Office of the Revisor of Statutes, State of Minnesota. https://www.revisor.mn.gov/statutes/cite/80A.461

Rigell, Laura. 2018. Solarize Philly: Advancing Equitable Solar Access in Philadelphia. ASES Conference presentation.

Schuh, Mike. 2018. "Ravens Legend Ray Lewis Starts Job Training Company For Convicted Felons." CBS Baltimore. https://baltimore.cbslocal.com/2018/03/28/ravens-ray-lewisjob-training-company-convicted-felons/

Sigrin, Benjamin, and Meghan Mooney. 2018. Rooftop Solar Technical Potential for Low-toModerate Income Households in the United States. Golden, CO: National Renewable Energy Laboratory.

Solar Holler. 2018. Solar Holler: Mine the Sun. Solar Holler. http://www.solarholler.com/

Solar in Your Community. 2018. Solar in Your Community Challenge Resources. Solar in Your Community Challenge. https://www.solarinyourcommunity.org/resources.html

U.S. Department of Energy. 2018. Business Energy Investment Tax Credit (ITC). Washington, D.C.: U.S. Department of Energy. https://www.energy.gov/savings/business-energy-investmenttax-credit-itc

Wells, Carrie. 2015a. "Ray Lewis Launches Clean Energy Non-Profit." The Baltimore Sun. https://www.baltimoresun.com/business/bs-bz-ray-lewis-solar-20151130-story.html

Wells, Carrie. 2015b. "Renters and Low-Income People Will Soon Be Able to Buy Solar Power Without Panels." The Baltimore Sun. https://www.baltimoresun.com/business/bs-bz-communitysolar-20151214-story.html 